This PDF is a selection from a published volume from the National Bureau of Economic Research

Volume Title: Preventing Currency Crises in Emerging Markets

Volume Author/Editor: Sebastian Edwards and Jeffrey A.

Frankel, editors

Volume Publisher: University of Chicago Press

Volume ISBN: 0-226-18494-3

Volume URL: http://www.nber.org/books/edwa02-2

Conference Date: January 2001

Publication Date: January 2002

Title: Dollarization of Liabilities, Net Worth Effects, and Optimal Monetary Policy

Author: Luis Felipe Céspedes, Roberto Chang, Andrés Velasco

URL: http://www.nber.org/chapters/c10644 


\title{
Dollarization of Liabilities, Net Worth Effects, and Optimal Monetary Policy
}

\author{
Luis Felipe Céspedes, Roberto Chang, and \\ Andrés Velasco
}

\subsection{Introduction}

Recent crises in emerging markets have caused the profession to reevaluate received wisdom about exchange rate regimes. In particular, analysis of the connection between imperfections in the financial sector and exchange rate policy has risen to the top of the research agenda. ${ }^{1}$ There are strong reasons for this focus. Both casual observation and formal econometric anal$y$ sis $^{2}$ suggest the existence of an empirical link between financial turmoil and currency crashes. Moreover, the question of whether central banks should defend their currencies against a speculative attack has emerged as a key and controversial aspect of the policy response, and this choice is increasingly governed by possible effects on the financial sector. Some analysts, such as Furman and Stiglitz (1998) and Radelet and Sachs (2000), have called for monetary expansion and depreciation in response to adverse shocks, reaffirming the validity of prescriptions derived from the conventional Mundell-Fleming analysis. Others, such as Calvo (2000), Dornbusch (1999), and Hausmann et al. (1999), have argued that in the presence of sizable dollar debts a sudden depreciation may do more harm than good.

In a previous paper (Céspedes, Chang, and Velasco 2000, henceforth

Luis Felipe Céspedes is an economist in the research department of the International Monetary Fund. Roberto Chang is associate professor of economics at Rutgers University. Andrés Velasco is Sumitomo Professor of International Finance and Development at the Kennedy School of Government, Harvard University.

The authors are grateful to Nouriel Roubini and conference participants for useful comments and discussion and to Paul Söderlind and Lars Svensson for Gauss programs. Of course, any errors or shortcomings are the authors' alone.

1. See Chang and Velasco (2000) for a detailed discussion of recent developments on this front.

2. The standard reference is Kaminsky and Reinhart (1999). 
CCV) we made an attempt to identify the role of financial imperfections in the design of exchange rate policy within a dynamic stochastic model with explicit microfoundations. CCV's model focuses on a small open economy that borrows in the world market to finance investment. Crucially, information frictions imply that the economy's borrowing, and hence aggregate demand, is constrained by its net worth, as emphasized by Bernanke and Gertler (1989). Exchange rate behavior may then exacerbate net worth effects because domestic residents borrow in foreign currency, whereas domestic income depends on the value of domestic money; or, in Calvo's (1999) parlance, the economy's liabilities are dollarized. In such a scenario a devaluation exerts, in addition to its conventional effects, a contractionary effect hitherto ignored in conventional literature. By weakening the economy's balance sheet, a devaluation exacerbates the effect of financial frictions, pushing down aggregate demand, output, and employment.

CCV's analysis yields at least two suggestions for the theory of exchange rate regimes. First, under reasonable parameter values, the coexistence of a net worth channel and liability dollarization may well imply a potentially contractionary channel of devaluation. Second, and somewhat surprisingly, the existence of such a channel does not justify defending the exchange rate against exogenous shocks, particularly real shocks from abroad. The reason is that adjustment to an exogenous shock requires a real devaluation, which will take place regardless of nominal exchange rate behavior; and it is real, not nominal, devaluation that determines the net worth effect. Hence, the unwanted effect of real devaluation on balance sheets will take place one way or the other, and exchange rate policy can only affect the manner and timing of the adjustment. In fact, under CCV's assumptions, fixed exchange rates emerge as being more contractionary than flexible rates, since the former imply that a real devaluation can only take place via price deflation, which, if nominal wages are rigid, exacerbates the contraction in employment and output.

To obtain analytically tractable closed-form solutions, in CCV we imposed very strong and simple assumptions about monetary policy. We compared a completely fixed exchange rate regime against a flexible rate regime that kept the price level fixed. Such a focus left unanswered the question of what is the optimal exchange rate regime in the presence of balance sheet effects and liability dollarization. That question can only be answered by specifying a social loss function and computing the optimal policy function under alternative shocks.

A related issue is that of credibility of policy - that is, ensuring that the monetary authority will not want to renege on an ongoing date- and statecontingent plan for the setting of its instruments. Optimal policy is meaningless unless it is also credible; this means that, in the absence of commitment devices, the relevant optimal policy is that computed under discretion. On the other hand, it is often argued that fixed exchange rates enjoy the ad- 
vantage of serving as a commitment device. This is relevant insofar as our result in $\mathrm{CCV}$ - that price-targeting rules are superior in welfare terms to exchange rate-targeting rules - could be meaningless if the latter are for some reason more credible than the former. The appropriate comparison then would be that of a fixed exchange rate regime against a credible (discretionary) policy of flexible rates.

The purpose of the present paper is to shed light on these questions. We study the determination of the optimal monetary and exchange rate policy with and without commitment and compare its implications (including welfare implications) to those of fixed exchange rates. Since it is key to confront these questions in the presence of financial imperfections, our framework is a version of the CCV model, extended to introduce money demand explicitly and to allow for staggered nominal wage-setting in the style of Calvo (1983).

To characterize optimal policy we assume that the central bank minimizes social loss, which is taken to be a function of income, inflation, and possibly real exchange rates. We compute the optimal policy with commitment, so that the monetary authority decides at the start of all time on the optimal policy path. More importantly, we also compute optimal policy under discretion, allowing the central bank to reoptimize and choose current policy at every point along the way. Under discretion and assuming rational expectations, market behavior must be consistent with future central bank strategy, which itself responds to market behavior. The outcomes of this interaction are given by the time-consistent equilibrium of the model, defined as in Oudiz and Sachs (1985) and Svensson (2000).

Under discretion, we consider three possibilities: the benchmark flexible inflation targeting, in which inflation and output fluctuations matter for social loss; strict inflation targeting, in which social loss depends only on inflation; and flexible inflation-cum-real exchange rate targeting, in which real exchange rate fluctuations are also present in the social loss function. We study the dynamic outcomes under the three discretionary regimes as well as under fixed exchange rates. Finally, we compare the social loss under commitment to the social loss under each discretionary regime and against the loss under fixed rates.

A main finding is that when the policy maker engages in flexible inflation targeting, whether under commitment or discretion, monetary policy relies on large changes in nominal and real exchange rates to deal with foreign shocks, a result that is similar to that obtained by Svensson (2000) in a very different model. Exchange rate flexibility is effective in stabilizing output fluctuations in our model, in spite of the presence of balance sheet effects and liability dollarization, and optimal policy exploits that effectiveness.

A second result is that fixed rates imply a loss not only larger than that of optimal policy under commitment, but also larger than each of the three discretionary regimes. The gains in output stabilization outweigh the losses 
from higher wage inflation. Hence, our model simulations provide no support for those who argue that, although an idealized floating regime might be desirable, real-life floating under discretion (and the attendant higher inflation) renders a simple fix superior in terms of welfare.

The quantitative results of the paper are also useful in assessing the validity of some commonly made claims about why emerging market countries "float the way they do," raising nominal interest rates in response to adverse shocks and apparently engaging in procyclical monetary policy (see Calvo 2000; Calvo and Reinhart 2002; and Hausmann et al. 1999). We find below that in a policy of pure fixing, the required nominal rate increase is smaller when responding to adverse export and foreign interest rate shock than under discretion and flexible inflation targeting. A short-sighted analysis would interpret this as evidence of fear of floating. However, that interpretation is wrong for two reasons. First, inflation is higher under floating, and hence the nominal rate is an uninformative indicator of the policy stance. Indeed, correcting for expected inflation reveals an expansionary, not deflationary, interest rate policy under flexible inflation targeting. Second, the optimal policy rule ${ }^{3}$ also adjusts the home interest rate down whenever investment is below its steady-state level. Since investment falls persistently after a bad shock from abroad, the initial rise in the nominal rate is typically very short-lived and often does not extend beyond an initial impact period. In short, highly variable nominal interest rates, or nominal rates that rise when adverse shocks hit, are not an indication of fear of floating.

The paper is organized as follows. Section 12.2 describes the economic environment. Section 12.3 computes benchmark optimal policy under discretion. Perfect commitment and fixed exchange rates are discussed and compared with the discretionary, flexible rate cases in section 12.4. Section 12.5 studies alternative specifications of the central bank objective function, and section 12.6 concludes.

\subsection{The Model}

As already mentioned, our basic environment is taken from CCV, extended to explicitly include money demand and to allow for overlapping wage contracts of the Calvo (1983) type. For the sake of brevity, here we only sketch the main aspects of the model and describe the two extensions just mentioned. For a more detailed exposition, the interested reader is referred to $\mathrm{CCV}$.

We focus on a small open economy that produces a single good using domestic labor and domestic capital. These two factors of production are owned by distinct agents called workers and capitalists. Workers consume

3. Again under discretion and flexible inflation targeting. 
and capitalists invest an aggregate of the home good and a single imported good. For simplicity, capitalists are assumed to consume only imports.

A crucial aspect of the model is that capitalists can invest in excess of their own net worth by borrowing abroad, but, because of informational asymmetries, the cost of borrowing exceeds the world interest rate and depends on the ratio of net worth to investment. Hence, the model features balance sheet effects of the kind stressed by Bernanke and Gertler (1989) that may be quantitatively important.

\subsubsection{Domestic Production}

The home good is produced by competitive firms with a common CobbDouglas technology that, in the neighborhood of the steady state, can be written as

$$
y_{t}=\alpha k_{t}+(1-\alpha) l_{t}, \quad 0<\alpha<1 .
$$

Here and in the rest of the paper, lowercase letters (except when noted) denote percentage deviations of the corresponding uppercase variables from their nonstochastic steady-state levels; ${ }^{4}$ for instance, if $Y_{t}$ denotes the level of output in period $t$ and $Y$ its steady state level, $y_{t}=\left(Y_{t}-Y\right) / Y$. Hence equation (1) is simply a log-linear version of the production function $Y_{t}=$ $A K_{t}^{\alpha} L_{t}^{1-\alpha}$, where $K_{t}$ and $L_{t}$ denote capital and labor inputs in period $t$.

As in Obstfeld and Rogoff (2000), workers are heterogeneous. Correspondingly, $L_{t}$ is assumed to be a constant elasticity of substitution (CES) aggregate of the services of the different home workers, and the market for labor exhibits monopolistic competition as in Dixit and Stiglitz (1977). The representative firm, however, takes all prices as given and chooses output and factor demands to maximize profits in every period. The main implication is that, in equilibrium, factor prices must equal marginal productivities, which (in percentage deviations from steady state) can be expressed as

$$
\begin{gathered}
r_{t}-p_{t}=y_{t}-k_{t}, \\
w_{t}-p_{t}=y_{t}-l_{t},
\end{gathered}
$$

where $p_{t}$ denotes the price of the home good, $r_{t}$ the rental rate of capital, and $w_{t}$ the aggregate wage (that is, $W_{t}$ is the minimum cost of obtaining a unit of $L_{t}$ ), all expressed in terms of the domestic currency (the peso).

The solution to the representative firm's problem also implies a downward-sloping demand curve for each worker's labor. Such a demand schedule is described later, when we discuss workers and the maximization problem they face. Finally, firm profits are zero in equilibrium. 


\subsubsection{Capitalists}

Capitalists finance investment with their own net worth and with foreign loans. However, because of informational asymmetries, foreign borrowing is subject to agency costs of the kind emphasized by Bernanke and Gertler (1989). This is the key ingredient for the model to feature balance sheet effects.

In every period, capitalists must invest for next period's capital, which is assumed to be a Cobb Douglas aggregate of home goods and imports. Imports have a fixed price in terms of a world currency, called the dollar. The law of one price holds and implies that the peso price of imports is equal to the nominal exchange rate. The implication is that the peso price of capital satisfies

$$
q_{t}=\gamma p_{t}+(1-\gamma) s_{t},
$$

where $\gamma$ is the share of home goods in the Cobb Douglas aggregator and $s_{t}$ is the nominal exchange rate.

To finance investment, capitalists use their net worth and also borrow from a world capital market in which the safe interest rate for dollars between $t$ and $t+1$ is random but known at $t$. However, the cost of borrowing abroad will be higher than the world interest rate because of informational problems. We follow Bernanke, Gertler, and Gilchrist (1999) and assume that the yield on investment is subject to idiosyncratic shocks that can be monitored by lenders only at a positive cost. This results in a costly state verification problem as in Townsend (1979) and Williamson (1987). The optimal contract to deal with this problem implies that there will be a divergence between the expected return on investment and the world interest rate, which can be written as

$$
\eta_{t+1}=\left[\left(r_{t+1}+k_{t+1}-s_{t+1}\right)-\left(q_{t}+k_{t+1}-s_{t}\right)\right]-\rho_{t} .
$$

For any variable $z_{t+j}$, the expression $z_{t+j}$ will denote the expectation of $z_{t+j}$ conditional on period $t$ information. Hence, in the right-hand side of equation (5), the term in square brackets is the expected dollar return on capital, given by the (log) difference between the dollar revenue from capital investment and the dollar cost of the investment. On the other hand, $\rho_{t}$ is the world interest rate on dollar loans between $t$ and $(t+1)$, expressed as a difference from its steady state value. Thus, $\eta_{t+1}$ represents the agency costs associated with external finance or, for short, a risk premium.

In turn, the optimal contract implies that

$$
\eta_{t+1}=\mu\left(q_{t}+k_{t+1}-p_{t}-n_{t}\right)
$$

where (close to the steady state) $\mu$ is a positive constant, and $n_{t}$ is the capitalist's net worth, expressed in terms of home goods. In words, equation (6) 
says that the risk premium is higher the larger the value of investment relative to net worth.

That investment is financed via foreign loans and net worth implies that

$$
q_{t}+k_{t+1}=\omega\left(s_{t}+d_{t+1}\right)+(1-\omega)\left(p_{t}+n_{t}\right),
$$

where $d_{t+1}$ is the amount borrowed at $t$ and due for repayment at $(t+1)$, and $\omega$ is the steady-state ratio of foreign borrowing to the dollar value of investment.

Next we describe the evolution of net worth. At the beginning of each period, capitalists collect the income from capital and settle their foreign debts. Then, a fraction $(1-\delta)$ of the capitalist population dies and is replaced by new capitalists. The dying capitalists consume their wealth; to simplify, we assume that they only consume imports. Consequently, $n_{t}$ is the aggregate net worth of the surviving capitalists, and its evolution is given by

$$
\begin{aligned}
n_{t} & =\chi\left(r_{t}+k_{t}-p_{t}\right)-(1-\chi)\left(\rho_{t-1}+s_{t}-p_{t}+d_{t}\right)-\zeta \eta_{t} \\
& =\chi y_{t}-(1-\chi)\left(\rho_{t-1}+s_{t}-p_{t}+d_{t}\right)-\zeta \eta_{t},
\end{aligned}
$$

where $\chi$ and $\zeta$ are positive constants that depend on the steady state. Intuitively, net worth increases with capital income and falls with debt repayments due at $t$. In addition, the term $\zeta \eta_{t}$ captures the fact that agency costs, which are directly related to the risk premium, raise the cost of servicing the debt due at $t$, and hence reduce net worth.

The second line of equation (8) implies that, ceteris paribus, a real devaluation of the peso (an increase in $s_{t}-p_{t}$ ) reduces net worth by increasing the relative burden of debt due at $t$. This is the crucial aspect of the model in $\mathrm{CCV}$ and implies that, in contrast with conventional analysis, a devaluation may have contractionary effects.

\subsubsection{Workers}

As mentioned earlier, labor services provided by individual workers are imperfect substitutes of each other. Consequently, each worker enjoys some monopoly power over the services he provides and, as in CCV, the labor market is monopolistically competitive, as in Dixit and Stiglitz (1977). We depart from CCV here by assuming that, as in Calvo (1983), only a random subset of the workers can set a new nominal wage each period. Moreover, we model money demand explicitly, which is useful to allow for different specifications of monetary policy. Because of these changes, we will be more detailed in our discussion of workers than in the rest of the model.

Workers are indexed by $i \in[0,1]$, and worker $i$ s preferences are given by the expectation of

$$
\sum_{t=0}^{\infty} \beta^{t}\left[\log C_{i t}-\left(\frac{\sigma-1}{\sigma}\right)\left(\frac{1}{v}\right) L_{i t}^{v}+\left(\frac{1}{1-\phi}\right)\left(\frac{M_{i t}}{Q_{t}}\right)^{1-\phi}\right] .
$$


In this expression $C_{i t}$ is an aggregate of home goods and imports; note that for simplicity we assume the same Cobb Douglas aggregator as the one relevant for investment, which implies that the peso price of consumption is $Q_{t}$. The variable $L_{i t}$ denotes $i$ 's supply of labor and $M_{i t}$ his peso holdings at the end of period $t$. Hence equation (9) simply says that worker $i$ enjoys consumption and money holdings, and dislikes working.

Worker $i$ 's choices include what to consume, how much to charge for the labor he supplies, and how many pesos to hold. In addition, each worker will hold a portfolio of securities, as will be described shortly. His constraints are of three types. First, he faces a downward demand curve for his labor services:

$$
L_{i t}=\left(\frac{W_{i t}}{W_{t}}\right)^{-\sigma} L_{t},
$$

where $W_{i t}$ is the peso price of $i$ 's labor services, that is, $i$ 's wage rate. As in Dixit and Stiglitz (1977), the worker is small enough so that he takes the evolution of $W_{t}$ and $L_{t}$ as given.

The second constraint is that, as in Calvo (1983), worker $i$ sets wages in pesos, and he can change his wage in period $t$ only with some probability ( 1 $-\theta$ ). Hence, with probability $\theta$, his nominal wage must be the same as in the previous period, and it is assumed that he must satisfy any demand forthcoming (as given by eq. [10]) ${ }^{5}$ at that wage.

Third, worker $i$ is restricted by his budget constraint. Note that, because different workers change wages at different times, workers are subject to idiosyncratic uncertainty. We assume that workers cannot borrow from abroad to smooth such uncertainty. However, and following Woodford (1996), we assume that workers can trade enough contingent securities among themselves to, in effect, insure completely against idiosyncratic shocks. This implies that the flow budget constraint of worker $i$ can be written as

$$
Q_{t} C_{i t}+M_{i t}+{ }_{t}\left(\Delta_{t, t+1} H_{i, t+1}\right)=W_{i t} L_{i t}+M_{i, t-1}+H_{i t}+T_{t},
$$

where $T_{t}$ is a peso transfer from the government; $H_{i t}$ is the peso value, at $t$, of the portfolio of contingent securities chosen at $(t-1)$; and $\Delta_{t, s}$ is the pricing kernel, such that the value at $t$ of a portfolio delivering the random payoff $H_{s}$ in period $s>t$ is ${ }_{t}\left(\Delta_{t, s} H_{s}\right)$.

As discussed by Woodford (1996), under our assumptions (together with a technical assumption to rule out Ponzi games), the budget constraint can be written in present value form. Assuming, in addition, that workers have identical initial wealth, it follows that they will completely

5. More precisely, the worker will provide labor elastically as long as the real wage is no smaller than the marginal disutility of working; beyond that, labor would be rationed. In what follows we assume that we are always in the nonrationing range. This can be ensured by considering exogenous shocks that are not "too large." 
pool their idiosyncratic risk and choose identical consumption plans and peso holdings.

One consequence is that the pricing kernel is given by the marginal rate of substitution between consumption at different dates and states

$$
\Delta_{t, s}=\beta^{s-t} \frac{Q_{t} C_{t}}{Q_{s} C_{s}},
$$

where $C_{t}$ denotes the consumption level common to all workers in period $t$. This implies, in particular, that the nominal interest rate at $t$, which we denote by $i_{t}^{\prime}$, must satisfy

$$
\frac{1}{1+i_{t}^{\prime}}={ }_{t} \Delta_{t, t+1}=\beta_{t}\left(\frac{Q_{t} C_{t}}{Q_{t+1} C_{t+1}}\right),
$$

as the inverse of $\left(1+i_{t}^{\prime}\right)$ is the price at $t$ of a sure peso at $t+1$.

Another consequence is that peso demand is given by

$$
\left(\frac{M_{t}}{Q_{t}}\right)^{-\phi}=\left(\frac{1}{C_{t}}\right) \frac{i_{t}^{\prime}}{1+i_{t}^{\prime}},
$$

which has the familiar interpretation that the marginal rate of substitution between money balances and consumption must equal its relative cost.

We assume that pesos are held only by workers and that the lump-sum transfer $T_{t}$ is the only way in which pesos are introduced in the economy. Hence, the supply of pesos satisfies $M_{t}=M_{t-1}+T_{t}$. Then, adding up equation (11) over $i$, and recognizing the fact that the net supply of contingent securities is zero, implies that

$$
Q_{t} C_{t}=W_{t} L_{t} .
$$

In other words, the value of workers' consumption in every period must equal the aggregate wage bill.

Note that, log-linearizing equations (12) and (14) around the steady state, and using equation (3), the deviation of $i_{t}^{\prime}$ from its steady-state level can be written as

$$
i_{t}={ }_{t} y_{t+1}-y_{t}+\left({ }_{t} p_{t+1}-p_{t}\right),
$$

which is an equation of the Fischer type.

Finally, worker $i$ must decide what wage to set in period $t$, assuming he is allowed to. This is a tedious problem and is discussed at length by Woodford (1996). The upshot is that the evolution of the aggregate wage is given by

$$
w_{t}-w_{t-1}=\left[\frac{1-\beta \theta}{1+\sigma(\nu-1)}\right]\left[\frac{v(1-\theta)}{\theta}\right] l_{t}+\beta\left({ }_{t} w_{t+1}-w_{t}\right) .
$$

This is a wage Phillips curve: wage inflation increases with expected future wage inflation as well as with labor employment. Intuitively, the reaction of 
the current aggregate wage to labor demand pressure is faster if nominal wages are less rigid, as given by a smaller $\theta$.

\subsubsection{Competitive Equilibrium}

To define equilibrium it remains to impose market clearing for home goods. Under our assumptions, domestic expenditure in home goods is a fixed fraction of final home expenditures. In addition, the home good can be sold to foreigners. As in Krugman (1999) and CCV, we assume that the value of home exports in dollars is exogenous. Clearing of the market for home goods then implies

$$
p_{t}+y_{t}=\lambda\left(q_{t}+k_{t+1}\right)+(1-\lambda)\left(s_{t}+x_{t}\right) .
$$

We must finally specify the stochastic processes driving the exogenous variables. Dollar exports are given by a first-order autoregression process

$$
x_{t}=a_{x} x_{t-1}+\varepsilon_{t}^{x},
$$

where $a_{x}$ is between zero and 1 , and $\varepsilon_{t}^{x}$ is white noise. Assume also that the world interest rate follows an $\mathrm{AR}(1)$ process

$$
\rho_{t}=a_{\mathrm{\rho}} \rho_{t-1}+\varepsilon_{t}^{\rho},
$$

where again $a_{\mathrm{\rho}}$ is between zero and 1 , and $\varepsilon_{t}^{\rho}$ is white noise.

This completes the description of the economic environment. Once monetary policy is specified, the system of equations (1) through (8) and (15) through (19) suffices to determine the dynamic behavior of $y, k, l, r, p, w$, $s, q, \eta, n, d, x, i$, and $\rho$. We can, therefore, turn to the study of monetary policy.

\subsection{Computing Optimal Policy}

In this section we analyze the policy choices of a monetary authority whose objective is to minimize expected social loss. Social loss is, in turn, assumed to depend on the deviations of output and inflation from their steady-state values and possibly on other variables. Our assumptions about the preferences of the policy maker are, we believe, realistic and may in particular reflect the existence of an inflation-targeting regime (as in Svensson 2000). Alternatively, our assumptions on social loss may be seen as an approximation to (some aggregate of) the welfare of workers and capitalists. ${ }^{6}$

As in much of the recent literature, we shall assume that the instrument of the monetary authority is the short nominal interest rate $i_{t}$. This implies

6. However, such an interpretation may require some additional assumptions to be accurate. See Kim and Kim (2002) and Benigno and Benigno (2000). 
that the behavior of monetary aggregates plays no essential role in the analysis: The money, in particular, adjusts passively as given by equation (14) and can be ignored.

As in Svensson (2000), the monetary authority's loss function is the unconditional expectation of a period loss function ${ }^{7}$ of the form

$$
\psi_{\pi} \pi_{t}^{2}+\psi_{y} y_{t}^{2}+\psi_{e} e_{t}^{2}
$$

where $e_{t}$ corresponds to the real exchange rate, or $s_{t}-p_{t}$. Hence, after taking expectations, the loss function becomes

$$
\psi_{\pi} \operatorname{Var}\left(\pi_{t}\right)+\psi_{y} \operatorname{Var}\left(y_{t}\right)+\psi_{e} \operatorname{Var}\left(e_{t}\right) .
$$

In the previous expressions, $\pi_{t}$ denotes the deviation of a measure of inflation from its steady-state value. In our benchmark computations, such a measure is given by wage inflation. The fact that we attribute social costs to wage inflation can easily be justified in the context of the Calvo (1983) staggering context. As Woodford $(1996,2000)$ shows in detail, with staggering inflation causes the dispersion of relative prices (or wages), and this is in turn costly for output and welfare. Because in our model it is wages that are sticky and staggered, it is ongoing wage inflation that causes such relative price distortions.

Notice that under this specification, the policy maker attempts to minimize the deviations of output from its steady-state or "natural rate" level, not from some higher threshold, as in some of the literature. This means that the "inflation bias" problem familiar from Barro and Gordon (1983) and related work is absent here. However, this does not mean that there is no time consistency problem: optimal policy computed under discretion and under commitment will in general not coincide. This is because, to the extent that wage setting depends on future economic conditions, a monetary policy that can commit to future actions may face an improved inflation-output trade-off in the short run (see Clarida, Galí, and Gertler 1999).

We begin with a benchmark regime corresponding to what Svensson (2000) terms flexible inflation targeting: $\psi_{\pi}=1, \psi_{y}=0.5$, and $\psi_{e}=0$. Social loss depends on inflation but also on domestic output. Later we analyze other regimes. ${ }^{8}$

\subsubsection{Parametrization}

We set the model parameters to ensure that the steady state is empirically plausible. Thus, the steady-state world real interest rate is 4 percent in annual terms. The share of the home good in the production of capital and in

7. It is well known that such an objective is the limit, as the discount factor goes to zero, of a scaled discounted sum of expected losses in all periods.

8. Notice that we follow Svensson's (1999) somewhat special terminology, which defines a regime not by the actions it involves, but by the loss function it minimizes. 
the consumption index, $\gamma$, is set at 0.75 , which is consistent with observed shares of imported goods in total output. The capital share in the production of the home good, $\alpha$, is assumed to be 0.35 .

We set $\theta$, the probability of nonadjustment in wages, to 0.75 , which implies that (on average) wages are adjusted every four quarters. The elasticity of demand for worker services, $\sigma$, and the elasticity of labor supply, $\nu$, are both set to be 2.0 .

We choose the rest of the parameters in the model to generate a steadystate risk premium of 600 basis points, a ratio of investment expenditures to debt that equals to 1.8 , and an annualized business failure rate of 8.8 percent. The monitoring costs are assumed to be 15 percent of the total assets of the firm in case of bankruptcy. Additionally, the fraction of capitalists surviving to the next period, $\delta$, is set to 0.9615 , while the idiosyncratic shock to the return of capital is assumed to be distributed log-normally with a standard deviation equal to 0.28 . Finally, the persistence parameter of the world interest rate and the export demand shocks is assumed to be 0.9 .

\subsubsection{Discretionary Policy}

In analyzing the policy problem, we find that it is crucial to specify when the monetary authority can commit to a particular choice. Begin with the case of discretion: the monetary authority sets $i_{t}$ in period $t$, after observing shocks in that period. The discretionary case is arguably the most relevant in practice. However, perhaps more importantly in our context, much of the recent debate on fixed versus flexible rates is based on the view that fixed rates may improve upon discretion by serving as an imperfect commitment device. Hence, evaluating such a view requires comparing outcomes under fixed rates against discretionary outcomes.

The policy maker's problem is to minimize social loss by choosing a strategy for setting $i_{t}$ in every period $t$ after observing the state of the economy and all shocks up to period $t$. To formalize this problem, it is useful to note that the dynamic system that determines the economy's equilibrium has a convenient state space representation. Letting $b_{t}=d_{t}+\rho_{t}$ denote aggregate debt repayment in period $t$, and letting $\pi_{t}=w_{t}-w_{t-1}$ denote wage inflation, one can write the model in the form

$$
\left(\begin{array}{c}
\mathbf{Z}_{t+1} \\
\mathbf{J}_{t+1}
\end{array}\right)=\boldsymbol{A}_{1}\left(\begin{array}{c}
Z_{t} \\
J_{t}
\end{array}\right)+\boldsymbol{A}_{2} i_{t}+\varepsilon_{t+1},
$$

where $\mathbf{Z}_{t}=\left(\rho_{t}, x_{t}, k_{t}, \eta_{t}, b_{t}, w_{t-1}\right)^{\prime}$ is a vector of predetermined variables at $t$, $\mathbf{J}_{t}=\left(s_{t}, p_{t}, \pi_{t}\right)^{\prime}$ is a vector of jumping variables, $\varepsilon_{t}=\left(\varepsilon_{t}^{\rho}, \varepsilon_{t}^{x}, 0,0, \ldots, 0\right)^{\prime}$ is a vector of exogenous shocks, and $\mathbf{A}_{1}$ and $\mathbf{A}_{2}$ are matrices whose coefficients are determined by the equilibrium system.

Given the state space equation (21), the techniques of Oudiz and Sachs (1985) and Backus and Driffill (1986) can be used to compute a discre- 
tionary outcome summarized by two linear maps. First, market behavior is given by a map

$$
\mathbf{J}_{t}=\mathbf{J Z}_{t},
$$

where $\mathbf{J}$ is a matrix defining values for the jumping variables at $t$ as a linear function of the predetermined ones.

Second, policy choices are given by

$$
i_{t}=\mathbf{f} \mathbf{Z}_{t},
$$

where $\mathbf{f}$ is a row vector defining the interest rate at $t$ as a linear combination of the predetermined variables.

The two linear maps thus defined have the property that (a) given the policy map in equation (23), the market behavior defined by equation (22) defines a rational expectations equilibrium of the economy given by equation (21), and (b) given the system in equation (21) and the market behavior in equation (22), the policy given by equation (23) in fact minimizes social loss subject to equations (21) and (22).

Once the maps in equations (22) and (23) are obtained, they can be used in equation (21) to arrive at the law of motion for the vector $\mathbf{Z}_{t}$. Then it is straightforward to obtain variances and covariances for all the variables in the model and therefore to compute the value of the social loss function.

The solution for the optimal policy rule turns out to be

$$
i_{t}=0.79 \rho_{t}-0.20 x_{t}+0.53 k_{t}+0.02 \eta_{t}+0.07 b_{t}-0.0 w_{t-1} .
$$

Several aspects of this rule warrant attention. The first is that the exchange rate floats, and considerably. The nominal interest rate adjusts to exogenous shocks, but not to the extent that would be necessary to stabilize the nominal and real exchange rates. Indeed, it is possible to solve for the exchange rate as a function of predetermined variables; the discretionary solution implies that the coefficients are nonzero. Equivalently, it is apparent from the impulse responses below that optimal policy requires flexible exchange rates.

In response to an increase of 100 basis points in the world interest rate $\rho_{t}$, the monetary authority increases the nominal interest rate by almost 80 basis points. At first glance, one may conjecture that this reflects that the monetary authority is partially defending the exchange rate. However, such an interpretation would be misleading for two reasons. First, $i_{t}$ is a nominal rate, and hence an increase in $i_{t}$ may merely be compensating for an increase in expected domestic inflation (see eq. [15]). Indeed, we shall see that domestic inflation increases after a rise in $\rho_{t}$. Second, the response of $i_{t}$ cannot be understood independently of the full dynamics of the model. This is because, when policy is given by equation (24), interest rates increase by more than 55 basis points if domestic capital is 1 percent above its steady-state 
Table 12.1

Unconditional Standard Deviations

\begin{tabular}{lccc}
\hline & \multicolumn{3}{c}{ Variables } \\
\cline { 2 - 4 } & $\pi_{t}$ & $y_{t}$ & $e_{t}$ \\
\hline Flexible inflation targeting & & & \\
$\quad$ Discretion & 0.44 & 0.04 & 2.77 \\
$\quad$ Commitment & 0.24 & 0.07 & 2.68 \\
Fixed exchange rate & 0.27 & 2.07 & 1.33 \\
\hline
\end{tabular}

value. Because an unexpected increase in the world interest rate will cause a fall in domestic investment and capital in subsequent periods, $i_{t}$ will increase very little, except for the very first period.

In response to an unexpected 1 percent increase in the demand for exports, the discretionary policy implies that the interest rate must fall on impact. Again, this is only the very short-run response and should not be taken as an indication of a procyclical monetary policy. In particular, a rise in $x_{t}$ will increase capital accumulation, which then will push interest rates up under the discretionary policy.

Table 12.1 shows the standard deviations of the variables of ultimate relevance for welfare. Under the discretionary policy in equation (24), the standard deviation of the real exchange rate is 2.77 , and the standard deviations of the nominal exchange rate and the price of the home goods are much higher. Hence, the optimal discretionary policy actively takes advantage of the ability to change the exchange rate, a finding similar to that of Svensson (2000). The main payoff is that output is stabilized almost completely. The standard deviation of (wage) inflation is also low ( 0.44 percent) but certainly not negligible, and is consistent with the high variability of the exchange rate.

Some further intuition can be obtained by studying the impulse response functions associated with equation (24), the discretionary solution. Figure 12.1 displays the responses to a 1 percent increase in the world interest rate. As we saw above, on impact the interest rate increases by 0.79 basis points over its steady-state value, but this increase is only temporary: after one period, the interest rate has fallen to only 2.5 basis points over its steady-state value, and from then on it converges slowly to the steady state.

Because capital depreciation is complete, the dynamic behavior of $i_{t}$ mirrors the adjustment of capital, which in turn responds to the real interest rate on loans. On impact, investment and capital fall more than one for one with the increase in the world interest rate. Investment then recovers gradually, as the real cost of loans falls. ${ }^{9}$ The latter reflects not only the return of the world interest rate to its steady state, but also a gradual fall in the risk

9. The real cost of loans corresponds to the world interest rate plus the risk premium and the expected real devaluation. 
OUTPUT

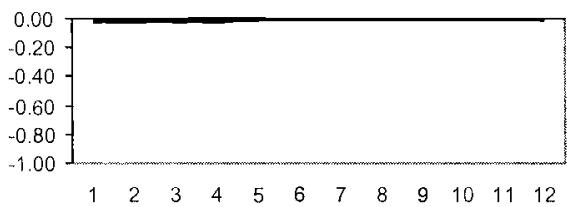

REAL EXCHANGE RATE

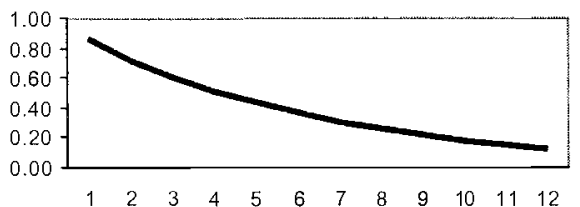

DEBT IN US\$

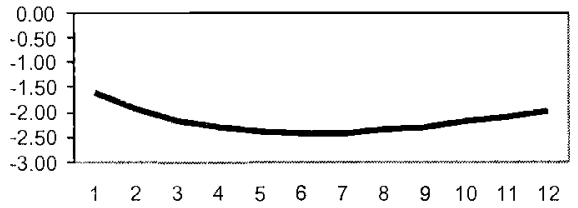

WAGE INFLATION

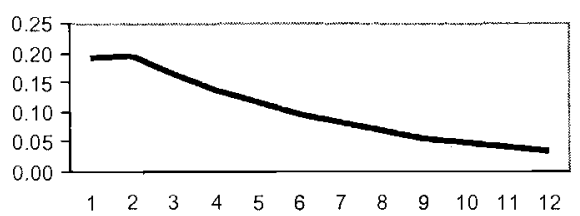

CONSUMPTION-BASED INTEREST RATE

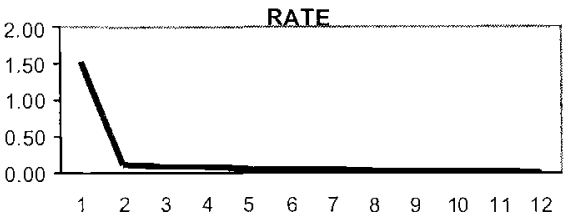

INVESTMENT

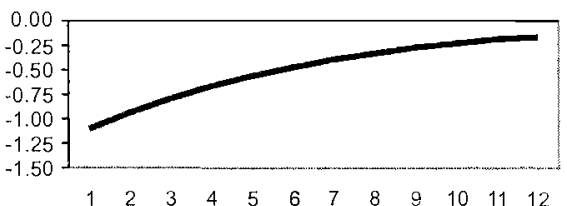

RISK PREMIUM

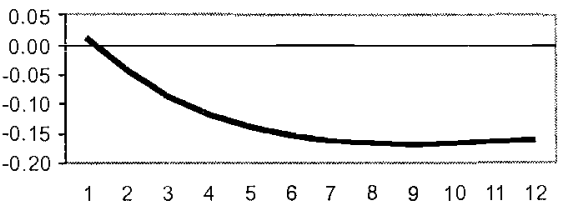

REAL COST OF LOANS

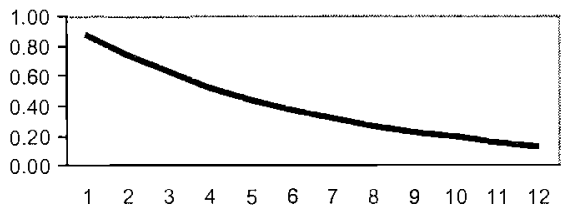

INTEREST RATE-MONETARY POLICY

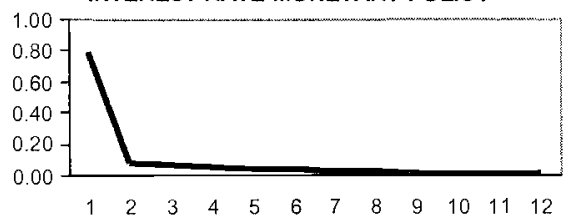

PRICE INFLATION

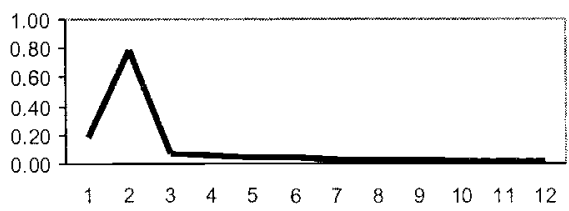

Fig. 12.1 Impulse responses to a world interest rate shock, discretion: Flexible inflation targeting 
premium below its steady-state level after an initial increase. The risk premium falls, in turn, because the interest rate increase reduces investment and foreign borrowing, which is apparent from figure 12.1. In fact, the reaction of foreign debt is quite strong, falling by almost 2.5 percent in the first six periods and then recovering slowly.

Finally, note that because capital adjusts toward the steady state only gradually, the discretionary rule in equation (24) limits the deviation of the home interest rate from its steady state. This confirms our previous observation that the optimal policy can only be interpreted in the context of the model's dynamic properties.

The impulse responses to a 1 percent decrease in export demand are given in figure 12.2. The shape of the response is the same as in the case of a world interest rate shock, although the magnitudes are smaller. The shock leads to a depreciation of the real exchange rate and to a fall in investment of 0.25 percentage points. Monetary policy almost perfectly stabilizes output. The shock and the associated monetary policy also lead to an increase in wage inflation.

\subsection{How Costly Is the Inability to Precommit?}

We now turn to the issue of quantifying the welfare loss associated with the absence of commitment. We start with a case of full commitment, in which the monetary authority can implement a date- and state-contingent policy specified at the start of time. We treat that case briefly, because it is unlikely to be of much relevance in practice. It is helpful, however, in providing a benchmark of how costly lack of commitment can be. We then turn to fixed exchange rates, considered as an imperfect but feasible commitment device. This is of interest because one may believe that some simple rules, including fixed exchange rate regimes, may be implementable even if they are time inconsistent. In such a case, fixed exchange rates may in principle be superior to the optimal policy under discretion, reflecting the stronger commitment associated with fixing.

\subsubsection{Optimal Policy under Full Commitment ${ }^{10}$}

Under full commitment, the optimal rule is generally not simply a map from period $t$ 's exogenous or predetermined variables to the policy or control variable $i_{t}$. That is because the monetary authority takes into account the whole future expected path of the economy. However, in period 0 it is indeed possible to write down such a representation, which turns out to be ${ }^{11}$

10. The calculations in this section follow Söderlind (1999).

11. The different is that actions at period zero are by definition unexpected, and hence the central bank does not have to worry about the effect of such actions on expectations along the equilibrium path. The same is not true of actions to be taken in some future period $T$, which affect expectations in all periods $t \leq T$. Technically, the difference is that for periods after $t=0$ the policy rule also contains a number of Lagrange multipliers, which are set to zero at time $t=0$. 
OUTPUT

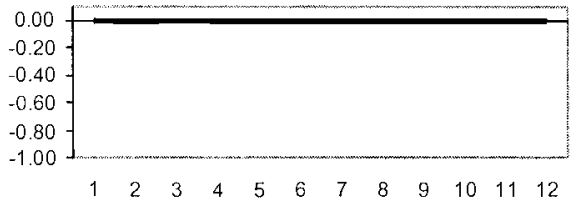

REAL EXCHANGE RATE

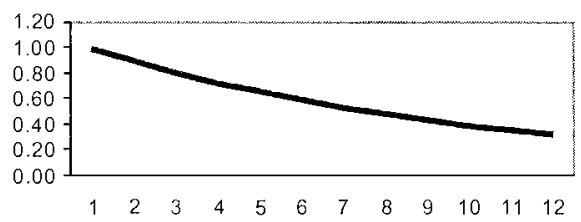

DEBT IN US\$

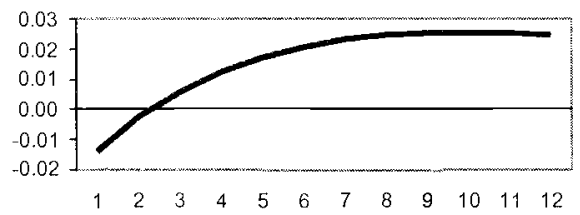

WAGE INFLATION

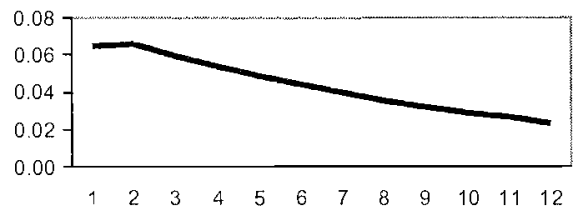

CONSUMPTION-BASED INTEREST RATE

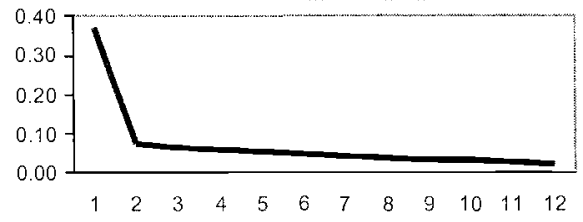

INVESTMENT

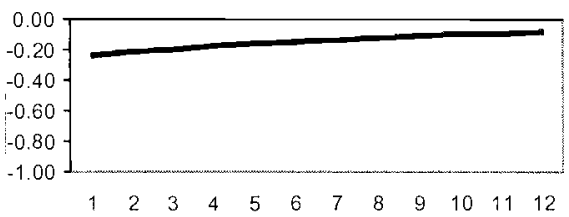

RISK PREMIUM

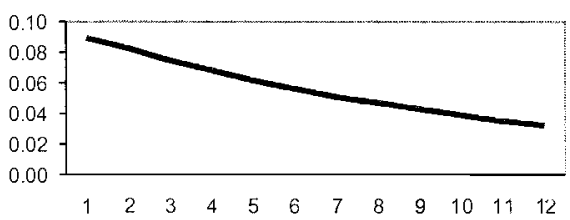

REAL COST OF LOANS

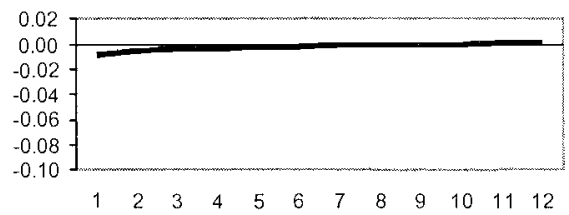

INTEREST RATE-MONETARY POLICY

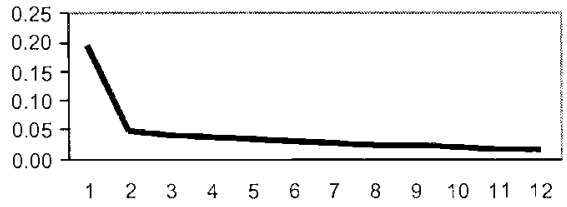

PRICE INFLATION

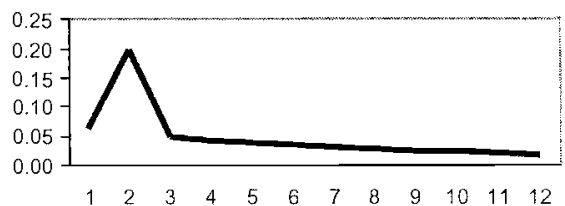

Fig. 12.2 Impulse responses to an export demand shock, discretion: Flexible inflation targeting 


$$
i_{t}=0.69 \rho_{t}-0.16 x_{t}+0.54 k_{t}+0.02 \eta_{t}+0.06 b_{t}-0.0 w_{t-1} .
$$

This rule is remarkably similar to the one under discretion. In particular, the exchange rate is again floating, in the sense that the domestic interest rate does not eliminate exchange rate fluctuations in response to shocks in external borrowing costs.

The main difference is that now the initial reactions of the nominal interest rate to foreign interest rate and export shocks are significantly smaller. Under commitment, less "toughness" is required from the central bank when it faces adverse circumstances. This is because a precommitting central bank can promise to engineer less inflation in the future; because price setting is forward looking, less expected inflation in the future means less actual inflation today, which in turn allows the central bank to choose a less restrictive level for domestic interest rate today.

Table 12.1 reveals that under commitment the standard deviation of output is slightly higher than under discretion, whereas that of inflation is much lower: 0.24 versus 0.44 percent. Interestingly, the policy maker who can commit also takes full advantage of the flexibility in relative prices implied by floating: now the standard deviation of the real exchange rate is 2.68 percent, only slightly below the 2.77 percent obtained under discretion. Moreover, the standard deviations of the nominal exchange rate and the price of the home good are significantly smaller compared to the discretionary case.

This general analysis can be enriched by examining the impulse response functions in figures 12.3 and 12.4. For concreteness, focus on the latter figure, which contains the case of a 1 percent adverse export shock. The main difference with discretion is in the behavior of wage inflation, which now peaks at half the value of the discretionary case. The lower inflation allows the monetary authority initially to raise nominal interest rates by less: 158 basis points, compared to 197 under discretion. As suggested by the standard deviation calculations, output falls by more and stays below the steady state longer under commitment. However, the size of these deviations is fairly small, and under commitment the output fall is more gradual and occurs later than under discretion.

Notably, the response of the risk premium is identical to that in the discretionary case. This may seem surprising, although not unexpected given our previous work. In the context of CCV we showed that, in equilibrium, the response of the risk premium was the same under fixed exchange rates and under a flexible rate, price-targeting policy. Our finding here is similar, although it refers to the response of the risk premium to different monetary rules. Indeed, we will see below that the change in the risk premium is the same across regimes, contrary to the conjectures in much of the recent policy literature.

The explanation for this result is straightforward: it can be shown with a bit of algebra (the details are in $\mathrm{CCV}$ ) that movements in the risk premium 
OUTPUT

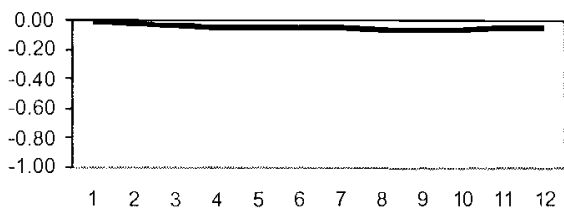

REAL EXCHANGE RATE

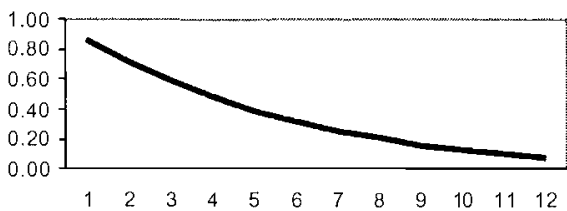

DEBT IN US\$

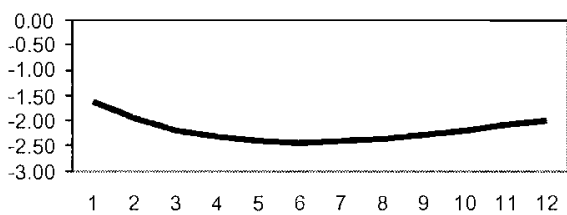

WAGE INFLATION

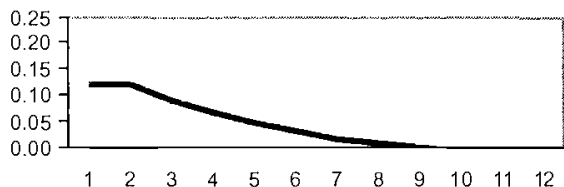

CONSUMPTION-BASED INTEREST

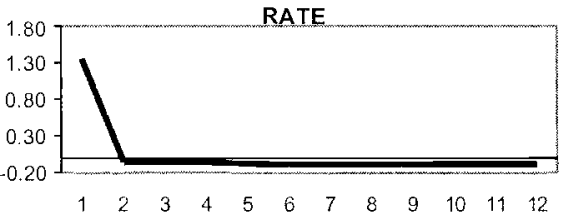

INVESTMENT

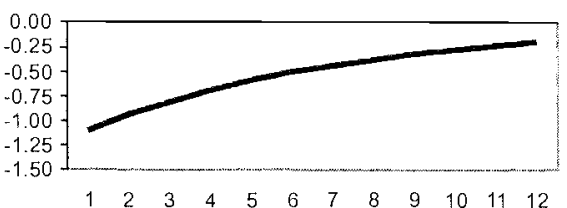

RISK PREMIUM

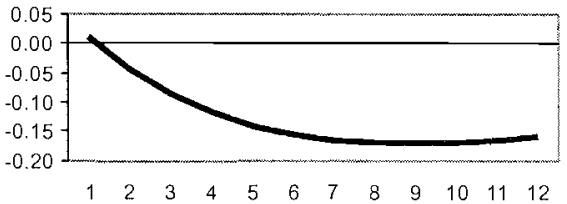

REAL COST OF LOANS

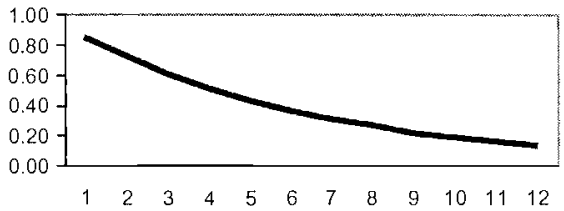

INTEREST RATE-MONETARY POLICY

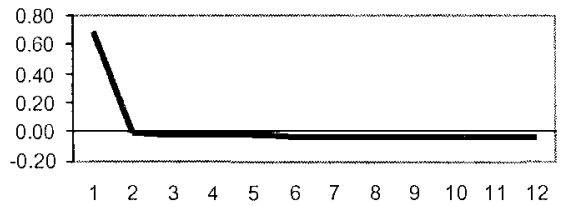

PRICE INFLATION

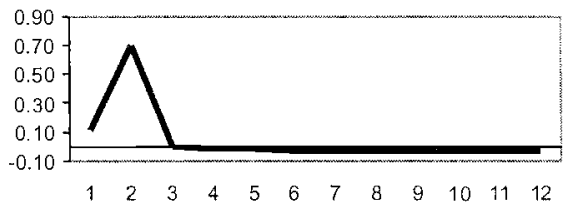

Fig. 12.3 Impulse responses to a world interest rate shock, commitment: Flexible inflation targeting 
OUTPUT

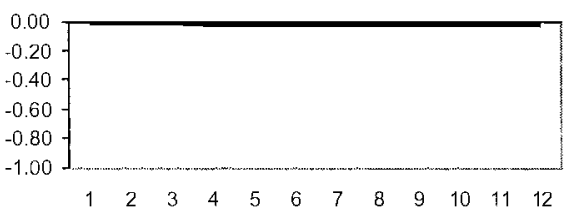

REAL EXCHANGE RATE

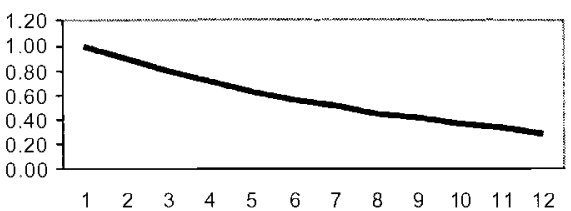

DEBT IN US\$

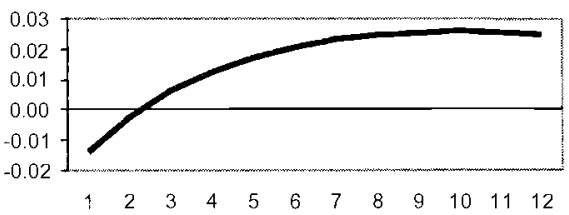

WAGE INFLATION

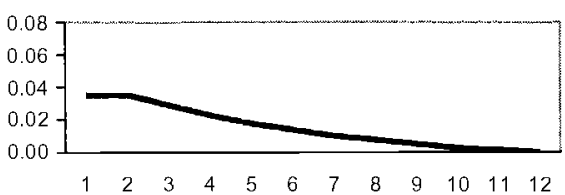

CONSUMPTION-BASED INTEREST

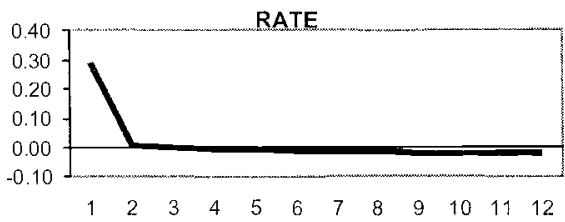

INVESTMENT

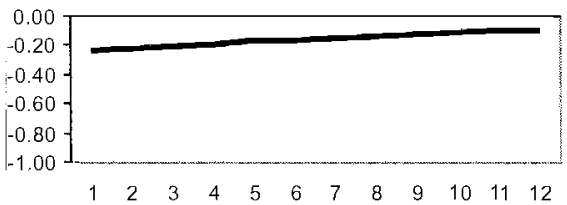

RISK PREMIUM

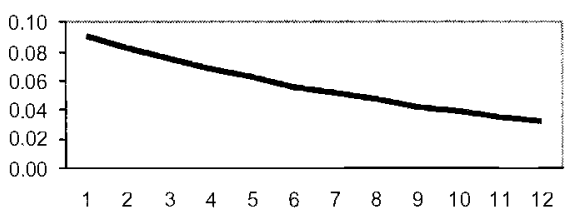

REAL COST OF LOANS

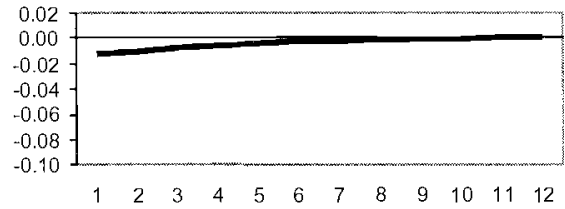

INTEREST RATE-MONETARY POLICY

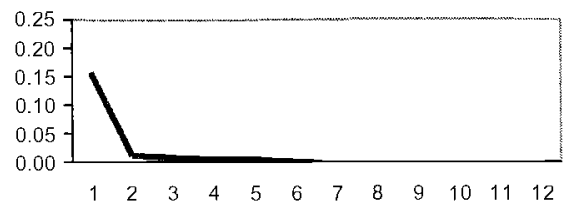

PRICE INFLATION

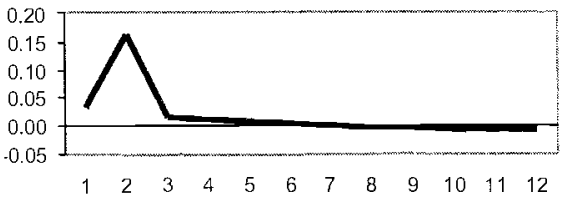

Fig. 12.4 Impulse responses to an export demand shock, commitment: Flexible inflation targeting 
depend on the response of overall dollar output. This is natural, as the risk premium depends on net worth relative to the value of investment, both of which depend on dollar output. Ultimately we find that in response to shocks, dollar output changes by the same amount independently of interest and exchange rate policy. Policy determines the split between movements in real output and movements in the real exchange rate.

\subsubsection{Fixed Exchange Rates}

Next we analyze the outcomes of the model under a fixed exchange rate regime. This is achieved by setting $s_{t}=0$, all $t$, as an equilibrium condition. Note that the nominal interest rate then responds passively to the resulting dynamic equilibrium and follows equation (15).

Under this policy the standard deviation of wage inflation falls to 0.27 percent, which reduces social loss relative to the discretionary solution. However, this is achieved at the price of an increase in the standard deviation of output from virtually zero in the flexible inflation targeting case to 2.07 percent.

Figure 12.5 shows the responses of the fixed rate regime to a 1 percent increase in the world interest rate. The nominal interest rate increases, on impact, by less than 15 basis points. It is interesting to note here that this increase is much less than the discretionary impact response, but this observation says little about the stance of monetary policy. With fixed rates the interest rate is endogenous, and the fact that the increase in the interest rate is relatively mild reflects the fact that, following the shock, there is strong price deflation and a fall in output.

Indeed, output falls by almost 0.5 percent on impact and by more than 0.85 percent in the second period, relative to its steady-state value. The response of investment and capital is even stronger: the short-run contraction is about 1.5 percent, and the recovery is relatively slow. In this case, inflation is negative for the first few periods and slightly positive in the medium run.

Finally, figure 12.6 presents the impulse responses of the economy to a 1 percent decrease in export demand. Again, output and investment reactions are stronger and more persistent than in the full commitment and discretionary policy cases.

These impulse responses suggest that, once the analysis goes beyond impact effects, fixed exchange rates exacerbate rather than ameliorating the adverse effects of financial frictions. This conjecture clearly warrants more research, if only because it contradicts the current conventional wisdom based on the existence of liability dollarization.

\subsubsection{Welfare Comparisons}

Table 12.2 compares the social loss associated with commitment, the discretionary case, and fixed exchange rates. By construction, welfare is highest under commitment. The main result is that welfare is lowest under fixed 
OUTPUT

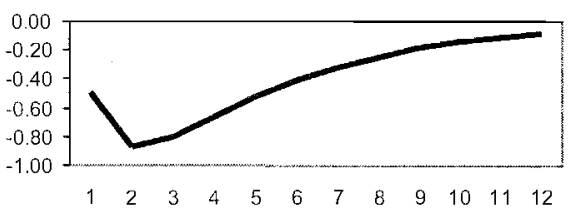

REAL EXCHANGE RATE

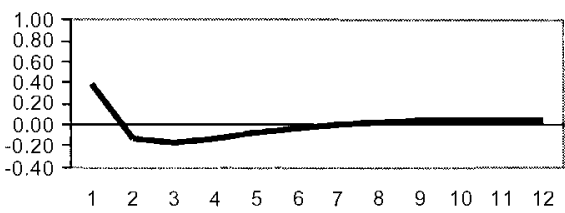

DEBT IN US\$

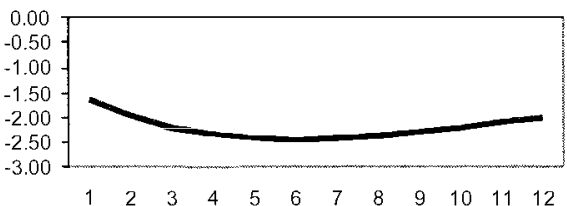

WAGE INFLATION

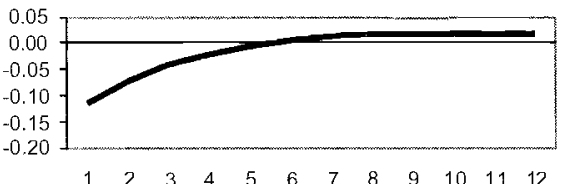

CONSUMPTION-BASED INTEREST

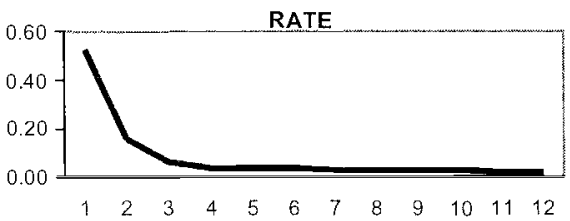

INVESTMENT

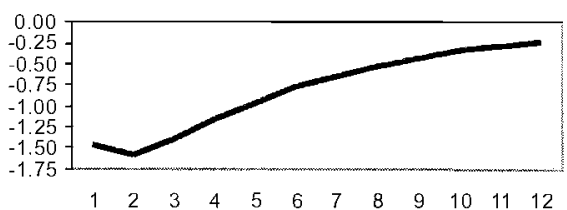

RISK PREMIUM

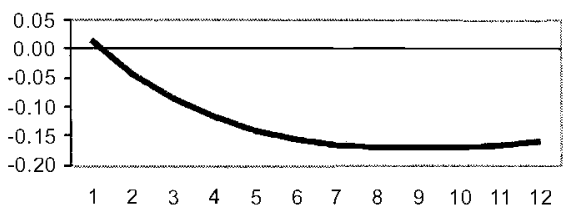

REAL COST OF LOANS

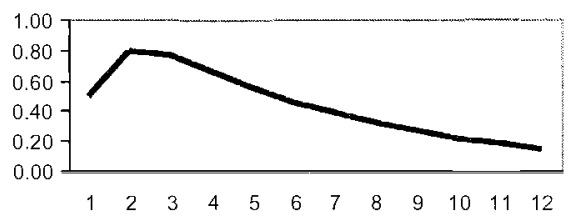

INTEREST RATE-MONETARY POLICY

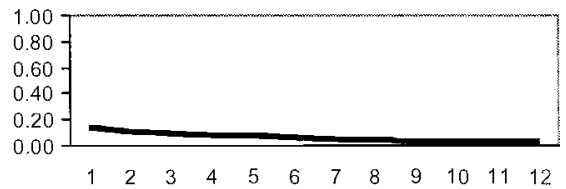

PRICE INFLATION

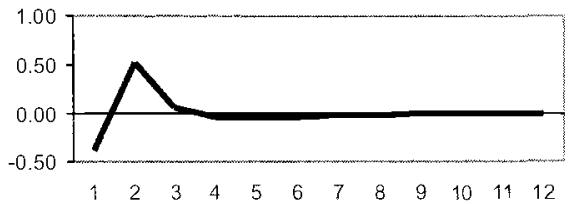

Fig. 12.5 Impulse responses to a world interest rate shock, fixed exchange rate 
OUTPUT

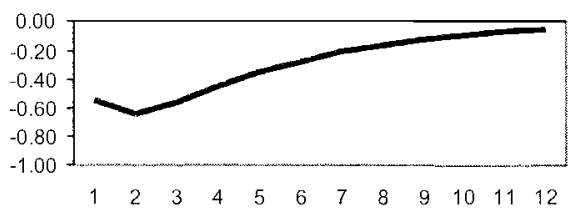

REAL EXCHANGE RATE

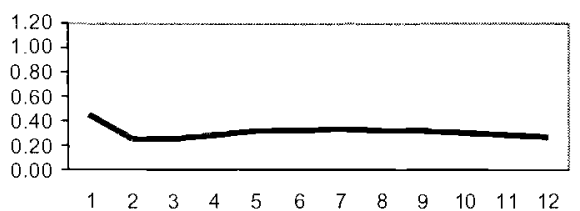

DEBT IN US\$

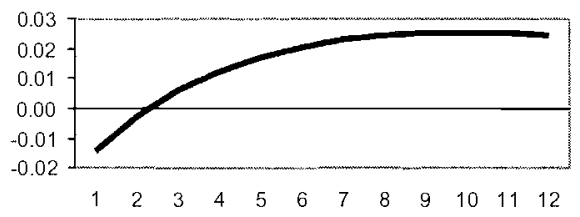

WAGE INFLATION

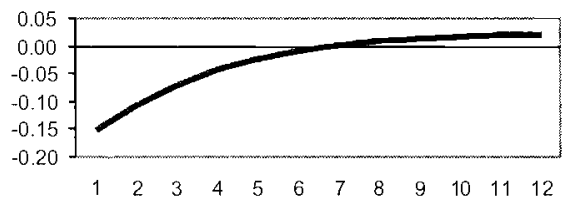

CONSUMPTION-BASED INTEREST

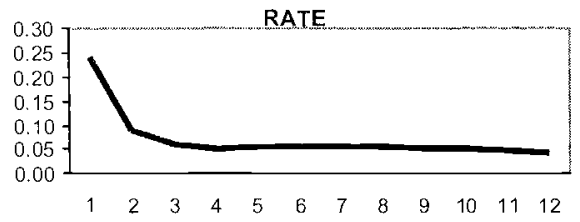

INVESTMENT

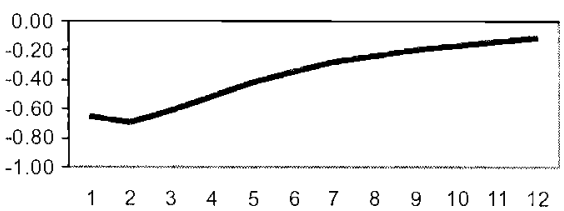

RISK PREMIUM

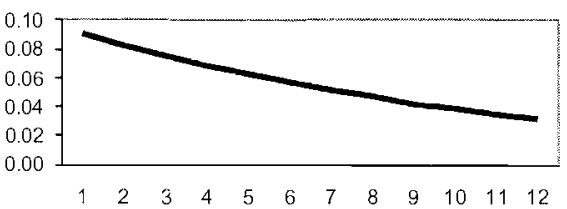

REAL COST OF LOANS

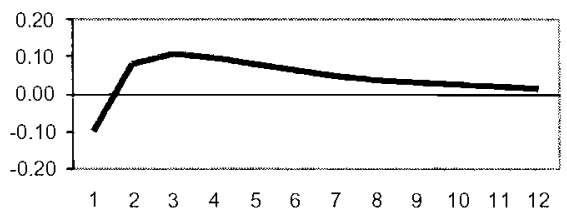

NTEREST RATE-MONETARY POLICY

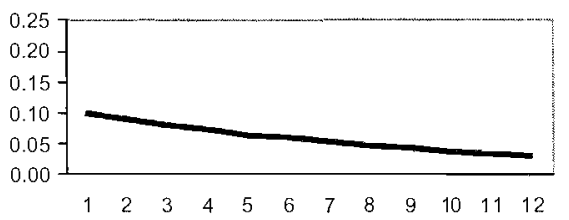

PRICE INFLATION

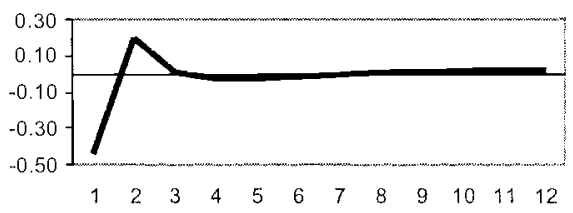

Fig. 12.6 Impulse responses to an export demand shock, fixed exchange rate 


\begin{tabular}{lc}
\hline & Loss Function Value \\
\hline Flexible inflation targeting & \\
Discretion & 0.20 \\
Commitment & 0.06 \\
Fixed exchange rate & 2.21 \\
\hline
\end{tabular}

exchange rates, and the difference is large: social loss is eleven times larger than under discretion and flexible inflation targeting. That is, the commitment gain associated with fixing does not even come close to offsetting the benefits of greater output stabilization under floating.

\subsection{Alternative Objective Functions}

What we have termed flexible inflation targeting is a plausible and practically relevant policy stance, but certainly not the only one. To make sure that our results - particularly the conclusion that flexible rates under discretion are preferable to fixed rates-do not depend on the particular specification of the loss function minimized by the central bank, we now analyze two alternative formulations: one with no concern for output stabilization and one in which the central bank attempts to stabilize the real exchange as well as the other two more conventional targets. For the sake of brevity, in what follows we omit the full commitment case.

\subsubsection{Strict Inflation Targeting}

Under a stance of strict inflation targeting the parameters of the loss function are $\psi_{\pi}=1, \psi_{y}=0$, and $\psi_{e}=0$. In other words, the monetary authority's sole objective is to stabilize wage inflation.

We discover that under strict inflation targeting the monetary authority finds it optimal to keep the interest rate unchanged in response to shocks. The intuition is that, given the wage Phillips curve in equation (16), wages and wage inflation can be held to their steady-state values if labor demand can also be held at its steady-state value. The latter can be achieved, by equation (3), if home nominal output is constant. However, equation (15) implies that home nominal output must be constant if the domestic short interest rate is constant. ${ }^{12}$

Table 12.3 confirms that, if inflation targeting is strict, the discretionary solution indeed manages to keep wage inflation constant. The change with respect to the flexible inflation targeting case is that output becomes more variable: the standard deviation of the output is almost 1 percent. However,

12. Note that, in this sense, a policy of keeping $i_{t}$ at its steady-state value is equivalent to a policy of "nominal GDP targeting," as studied by Frankel and Chinn (1995). 


\begin{tabular}{lccc}
\hline & \multicolumn{3}{c}{ Variables } \\
\cline { 2 - 4 } & $\pi_{t}$ & $y_{t}$ & $e_{t}$ \\
\hline Flexible inflation targeting & 0.44 & 0.04 & 2.77 \\
Strict inflation targeting & 0.00 & 0.96 & 2.29 \\
Flexible inflation-RER targeting & 0.49 & 1.39 & 1.42 \\
Fixed exchange rate & 0.27 & 2.07 & 1.33 \\
\hline
\end{tabular}

Note $:$ RER = real exchange rate.

this is intuitive, as output variability implies no loss under strict inflation targeting. The standard deviation of the real exchange rate turns out to be 2.29 percent, somewhat lower than under flexible inflation targeting.

Figure 12.7 shows the response of the economy to a 1 percent increase in the world interest rate for the case of strict inflation targeting. As one might expect, output and investment exhibit stronger and more persistent falls under strict inflation targeting than in the flexible targeting case. Interestingly, output has a hump-shaped response, which replicates some existing vector autoregression evidence without relying on assumptions about the timing of investment. Even though the increase on impact of the real exchange rate under strict inflation targeting is similar to that in the flexible case, its persistence is lower.

The response of the economy to a 1 percent fall in export demand appears in figure 12.8. Again, monetary policy completely stabilizes inflation. Compared to flexible inflation targeting, strict inflation targeting results in a deeper contraction in output and investment. Whereas the reaction of the real exchange rate is rather similar in shape and magnitude, the depreciation (increase) of the nominal exchange rate (price of the home goods) is smaller under strict inflation targeting.

\subsubsection{Flexible Inflation and Real Exchange Rate Targeting}

In a third and last case under discretion, we allow the variance of the real exchange rate to affect the monetary authority's loss function. This can be termed flexible inflation-cum-real exchange rate targeting. Assuming that the exchange rate objective is as important to the central bank as the output objective, we chose $\psi_{\pi}=1, \psi_{y}=0.5$, and $\psi_{e}=0.5$ to represent this case. Under dollarization of liabilities there are especially powerful reasons that the monetary authority may want to stabilize the real exchange rate, because we have seen that sharp sudden devaluations typically have nasty effects on balance sheets.

The solution for the policy rule is

$$
i_{t}=0.93 \rho_{t}-0.22 x_{t}+0.53 k_{t}+0.02 \eta_{t}+0.08 b_{t}-0.0 w_{t-1} .
$$



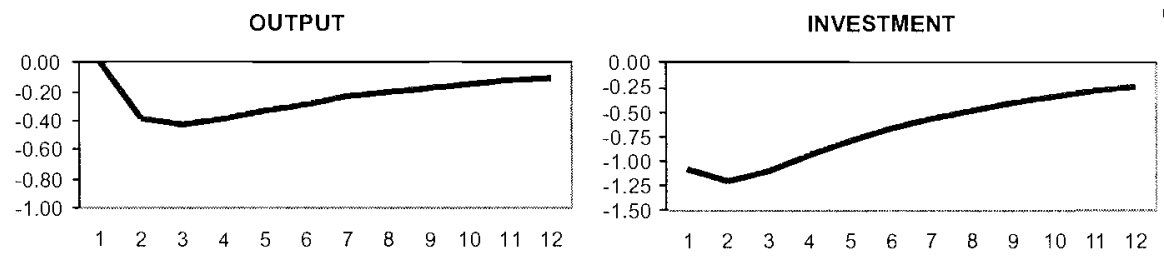

REAL EXCHANGE RATE

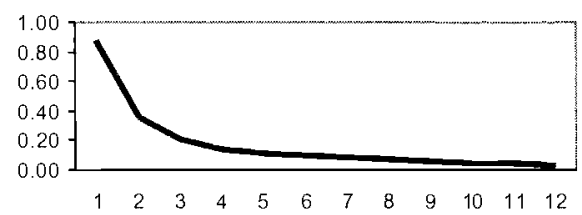

RISK PREMIUM

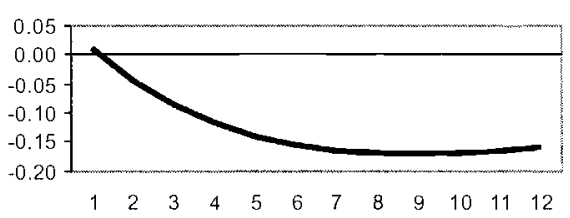

DEBT IN US\$

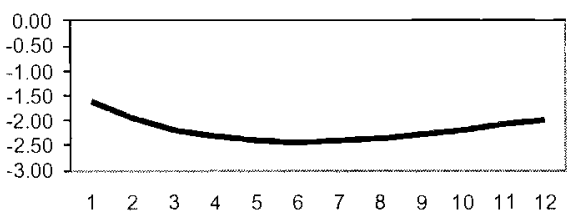

REAL COST OF LOANS

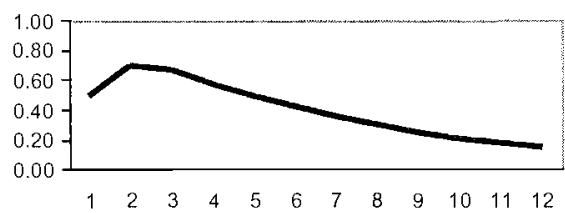

WAGE INFLATION

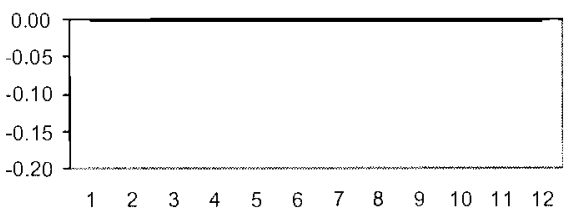

INTEREST RATE-MONETARY POLICY

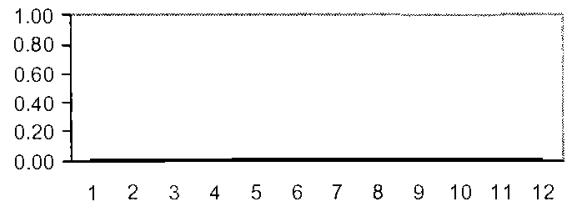

CONSUMPTION-BASED INTEREST

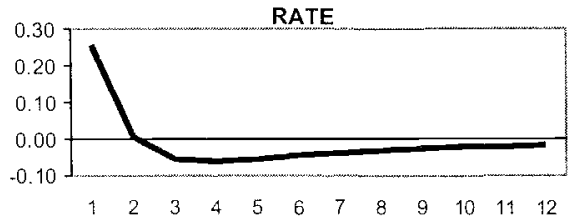

PRICE INFLATION

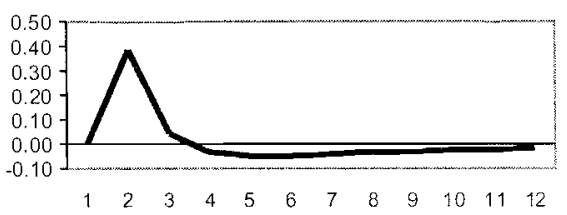

Fig. 12.7 Impulse responses to a world interest rate shock, strict inflation targeting 
OUTPUT

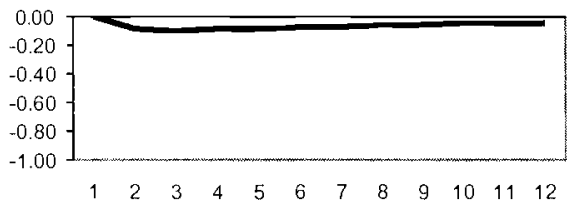

REAL EXCHANGE RATE

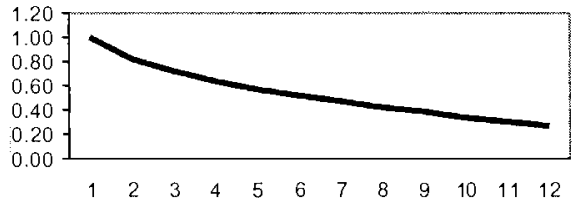

DEBT IN US\$

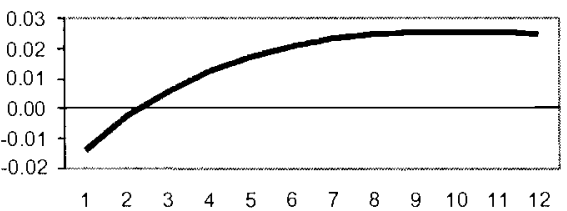

WAGE INFLATION
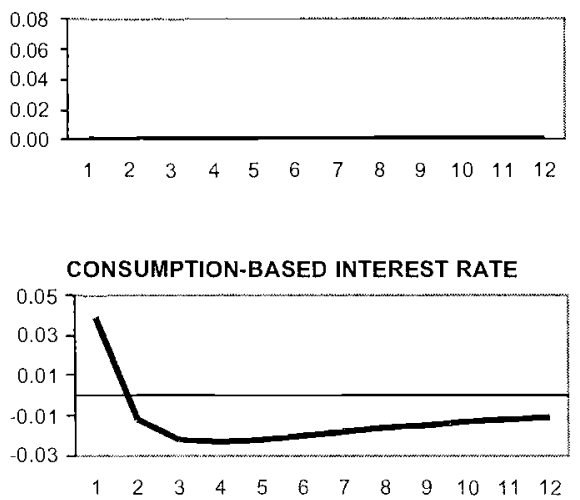

INVESTMENT

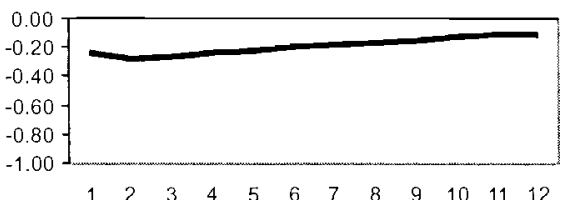

RISK PREMIUM

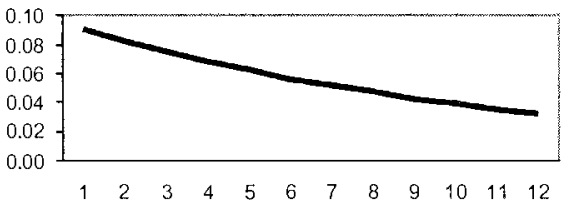

REAL COST OF LOANS

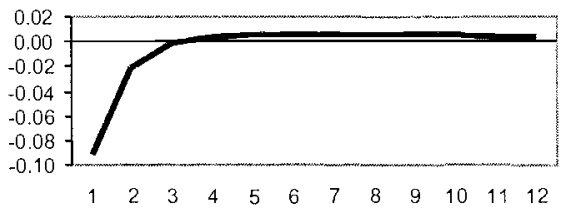

INTEREST RATE-MONETARY POLICY

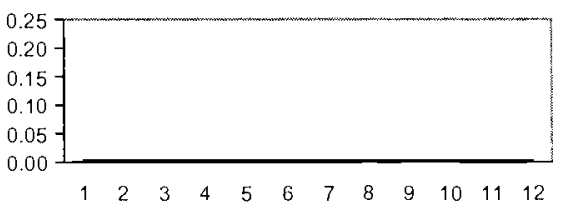

PRICE INFLATION

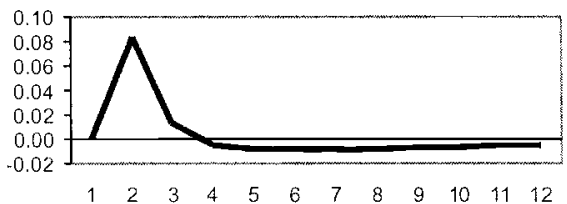

Fig. 12.8 Impulse responses to an export demand shock, strict inflation targeting 
Now, in response to an increase of 100 basis points in the world interest rate the monetary authority increases the nominal domestic interest rate by more than 90 basis points. Naturally, this reaction is stronger than in the flexible inflation targeting case. The rest of the coefficients are quite similar to the ones in that case.

As can be seen from table 12.3, flexible inflation-exchange rate targeting implies that inflation and output are more variable and the real exchange rate less variable than in the two previous cases. This is not surprising, because the monetary authority now prefers to reduce exchange rate volatility at the cost of more variable inflation and output. In fact, the standard deviation of output in this regime is almost 50 percent higher than strict inflation targeting and more than thirty-five times higher than under flexible inflation targeting. The standard deviation of the real exchange rate is half the standard deviation under flexible inflation targeting and 40 percent lower than under strict inflation targeting.

Figure 12.9 presents the impulse responses to a 1 percent increase in the world interest rate. The initial fall of output is stronger compared to both flexible and strict inflation targeting. Investment is also lower. However, the initial response of the real exchange rate is reduced by almost one-half. Wage inflation is lower than in the flexible inflation targeting but higher than in the strict inflation targeting. The response of the risk premium is identical to that in the two previous cases.

Finally, figure 12.10 displays the response of the economy to a 1 percent decrease in export demand. Notice that in the first period the interest rate increases, but thereafter monetary policy turns clearly expansionary. Moreover, output and investment exhibit a stronger fall compared to the previous cases under discretion. The real exchange rate reaction is less pronounced and inflation is in fact negative under this particular specification of the central bank objectives.

\subsubsection{Welfare Comparisons}

Table 12.4 compares the social loss associated with both these discretionary cases with the loss under fixed exchange rates. For each discretionary alternative, the loss under fixed rates is evaluated using the weights in the welfare function associated with that alternative.

Again, social loss is larger under fixed rates than under either discretionary solution. The disadvantages of fixed rates appear to be larger if output enters the social loss function. Conversely, fixed rates seem almost as good as flexible rates if in the latter case there is strict inflation targeting.

\subsection{Final Remarks}

We have found that, even if fixed exchange rates enjoy a credibility advantage, they do not yield higher welfare than does optimal floating under 
OUTPUT

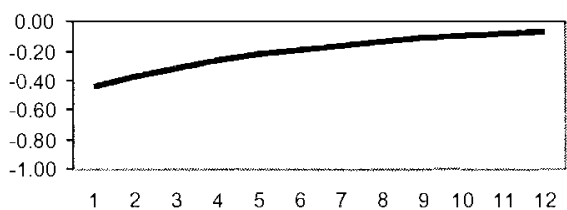

REAL EXCHANGE RATE

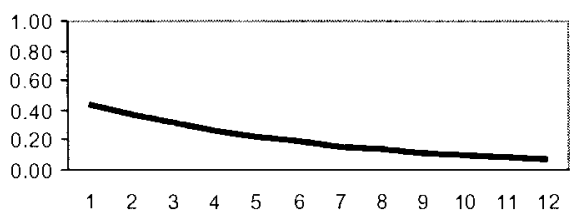

DEBT IN US\$

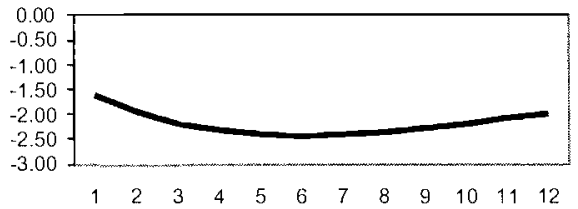

WAGE INFLATION

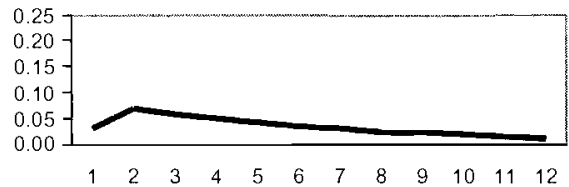

CONSUMPTION-BASED INTEREST RATE

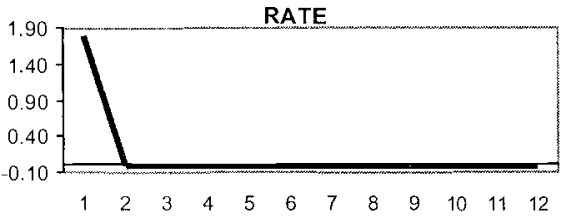

INVESTMENT

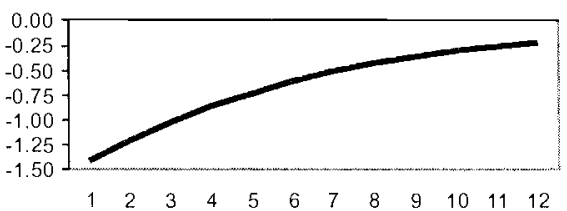

RISK PREMIUM

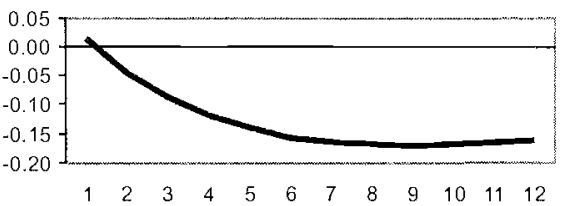

REAL COST OF LOANS

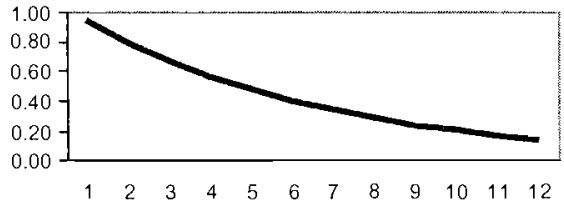

INTEREST RATE-MONETARY POLICY

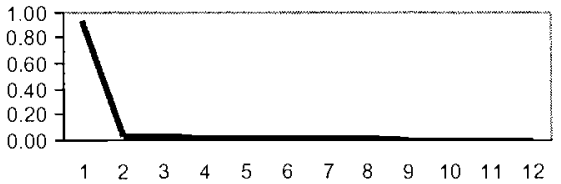

PRICE INFLATION

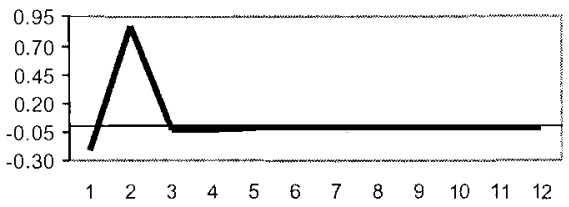

Fig. 12.9 Impulse responses to a world interest rate shock, flexible inflationreal exchange rate targeting 

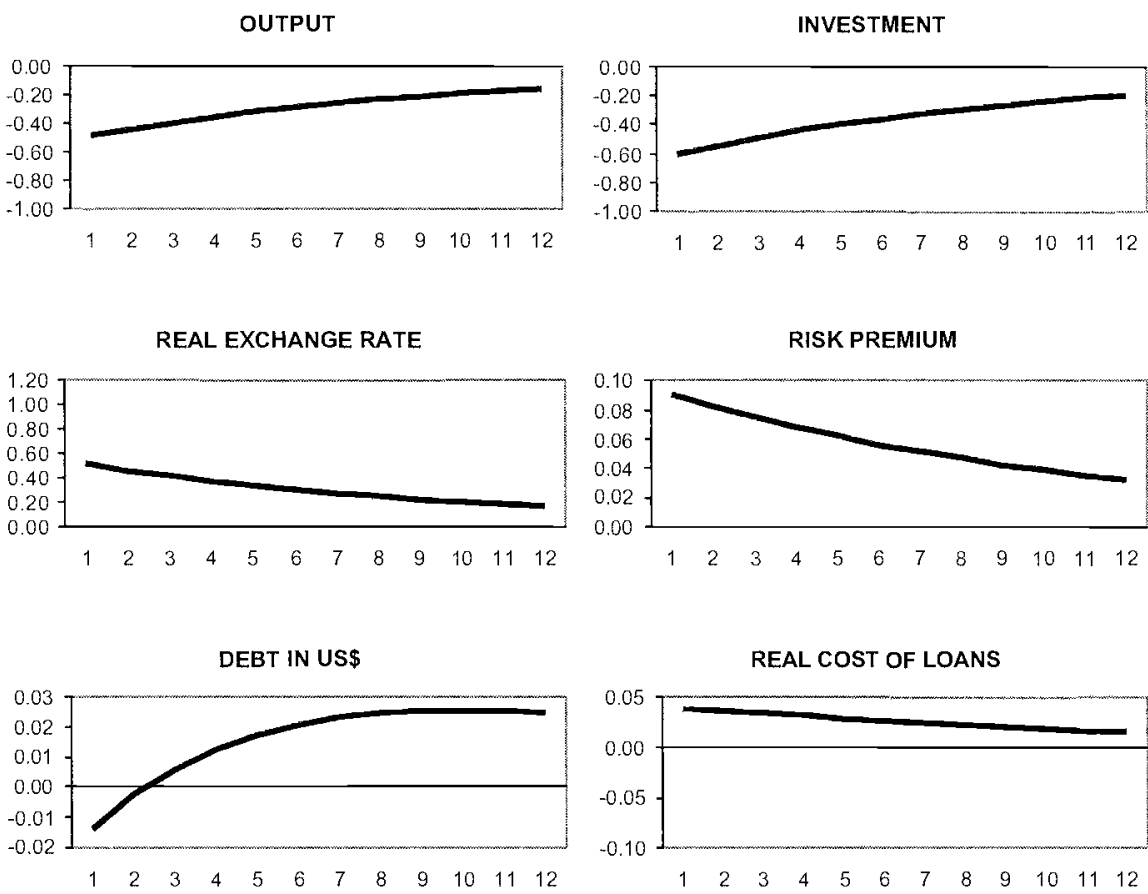

WAGE INFLATION

INTEREST RATE-MONETARY POLICY
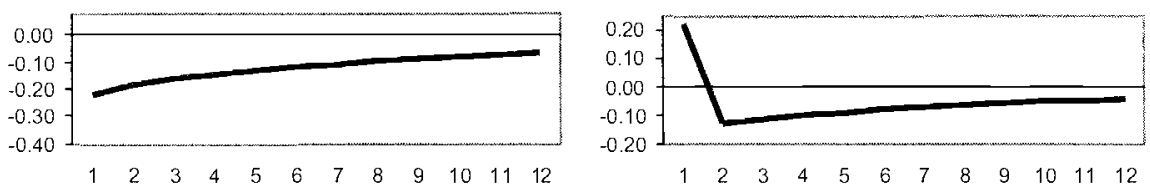

CONSUMPTION-BASED INTEREST
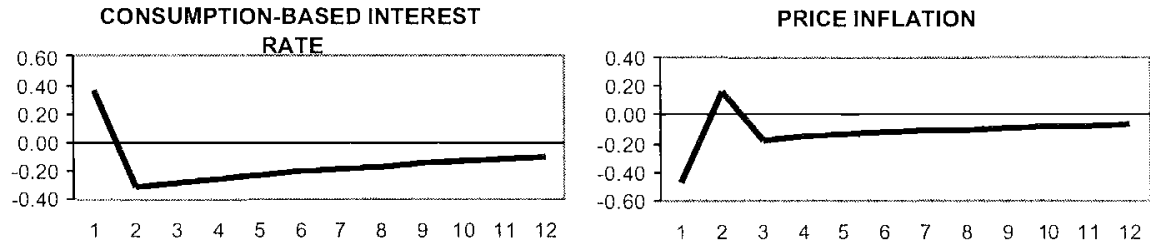

Fig. 12.10 Impulse responses to an export demand shock, flexible inflationreal exchange rate targeting 


\begin{tabular}{lcc}
\hline & \multicolumn{2}{c}{ Loss Function Value } \\
\cline { 2 - 3 } & (Col. 1) & (Col. 2) \\
\hline Flexible inflation targeting vs. fixed exchange rate & 0.20 & 2.21 \\
Strict inflation targeting vs. fixed exchange rate & 0.00 & 0.07 \\
Flexible inflation-RER targeting vs. fixed exchange rate & 2.21 & 3.10 \\
\hline
\end{tabular}

Note $:$ RER = real exchange rate.

discretion. Fixing turns out to have adverse consequences for aggregate real variability, particularly of output. This outweighs the inflation gains associated with fixed rates. This conclusion does not depend on-instead, it seems to be reinforced by - the existence of financial imperfections that interact with net worth effects. Naturally, these findings must be checked further for robustness, under alternative parameters and model specifications. However, it is notable that they are consistent with our previous theoretical analysis in CCV.

Of the many extensions suggested by the analysis, perhaps the most obvious one is to drop the ad hoc specification of the monetary authority's loss function in favor of a true social welfare function derived from microfoundations, as in Woodford $(1996,2000)$ and Rotemberg and Woodford (1997). This involves not only aggregating the interests of agents in the home population, but also finding a tractable way to do so. This task is not trivial, because here there are a number of distortions (financial frictions in addition to sticky prices and monopoly power) and therefore Taylor approximations to the social objective function may not always yield the quadratic forms we have relied on. On the other hand, the recent work of Chang (1998), Phelan and Stachetti (2002), and Sleet (2001) suggests that there may be computationally feasible ways to tackle directly the nonlinear discretionary policy problem without relying on linear-quadratic approximations.

\section{References}

Backus, D., and J. Driffill. 1986. The consistency of optimal policy in stochastic rational expectations models. CEPR Discussion Paper no. 124. London: Center for Economic Policy Research.

Barro, R., and D. Gordon. 1983. A positive theory of monetary policy in a natural rate model. Journal of Political Economy 91:589-610.

Benigno, G., and P. Benigno. 2000. Price stability as a nash equilibrium in monetary open-economy models. New York University. Unpublished Manuscript, October. 
Bernanke, B., and M. Gertler. 1989. Agency costs, net worth, and business fluctuations. American Economic Review 79:14-31.

Bernanke, B., M. Gertler, and S. Gilchrist. 1999. The financial accelerator in a quantitative business cycle framework. In Handbook of macroeconomics, ed. J. Taylor and M. Woodford, 1341-93. Amsterdam: North-Holland.

Calvo, G. 1983. Staggered prices in a utility maximizing framework. Journal of Monetary Economics 12:383-98.

. 1999. Fixed vs. flexible exchange rates: Preliminaries of a turn-ofmillennium rematch. May. Available at [http://www.bsos.umd.edu.econ/ciecalvo. htm].

2000. Capital market and the exchange rate with special reference to the dollarization debate in Latin America. April. Available at [http://www.bsos.umd. edu/econ/ciecalvo.htm].

Calvo, G., and C. Reinhart. 2002. Fear of floating. Quarterly Journal of Economics, forthcoming.

Céspedes, L., R. Chang, and A. Velasco. 2000. Balance sheets and exchange rate policy. NBER Working Paper no. 7840. Cambridge, Mass.: National Bureau of Economic Research, August.

Chang, R. 1998. Credible monetary policy in an infinite horizon model: Recursive approaches. Journal of Economic Theory 81:431-61.

Chang, R., and A. Velasco. 2000. Exchange rate regimes for developing countries. American Economic Review 90 (2): 71-75.

Clarida, R., J. Galí and M. Gertler. 1999. The science of monetary policy: A new Keynesian perspective. Journal of Economic Literature 37 (December): 1661-707.

Dixit, A., and J. Stiglitz. Monopolistic competition and optimum product diversity. American Economic Review 67:297-308.

Dornbusch, R. 1999. After Asia: New directions for the international financial system. MIT, Department of Economics. Mimeograph. Available at [http:// web.mit.edu/rudi/www/ ].

Frankel, J., and M. Chinn. 1995. The stabilizing properties of a nominal GDP rule. Journal of Money, Credit, and Banking 27 (May): 318-34.

Furman, J., and J. Stiglitz. 1998. Economic crises: Evidence and insights from East Asia. Brookings Papers on Economic Activity, Issue no. 2:1-135.

Hausmann, R., M. Gavin, C. Pagés-Serra, and E. H. Stein. 1999. Financial turmoil and choice of exchange rate regime. IADB Working Paper no. WP-400. Washington, D.C.: Inter-American Development Bank, January.

Kaminsky, G., and C. Reinhart. 1999. The twin crises: The causes of banking and balance of payments problems. American Economic Review 89 (June): 473-500.

Kim, J., and S. Kim. 2002. Spurious welfare reversal in international business cycle models. Journal of International Economics, forthcoming.

Krugman, P. 1999. Balance sheets, the transfer problem and financial crises. In International finance and financial crises, ed. P. Isard, A. Razin, and A. Rose, 31-44. Boston: Kluwer Academic Publishers.

Obstfeld, M., and K. Rogoff. 2000. New directions for stochastic open economy models. Journal of International Economics 50:117-54.

Oudiz, G., and J. Sachs. 1985. International policy coordination in dynamic macroeconomic models. In International policy coordination, ed. W. Buiter and R. Marston, 274-319. Cambridge: Cambridge University Press.

Phelan, C., and E. Stachetti. 2002. Subgame perfect equilibria in a Ramsey taxes model. Econometrica, forthcoming.

Radelet, S., and J. Sachs. 2000. The onset of the Asian financial crisis. In Currency crises, ed. P. Krugman, 105-53. Chicago: University of Chicago Press. 
Rotemberg, J., and M. Woodford. 1997. An optimization-based framework for the conduct of monetary policy. In NBER macroeconomics annual, ed. B. Bernanke and J. Rotemberg, 297-346. Cambridge: MIT Press.

Sleet, C. 2001. On credible monetary policy and private government information. Journal of Economic Theory 99 (July): 338-76.

Söderlind, P. 1999. Solution and estimation of RE macromodels with optimal policy. European Economic Review 43:813-23.

Svensson, L. 1999. Inflation targeting as a monetary policy rule. Journal of Monetary Economics 43:607-54. $50: 155-84$.

Townsend, R. 1979. Optimal contracts and competitive markets with costly state verification. Journal of Economic Theory 21:265-93.

Williamson, S. 1987. Costly monitoring, loan contracts, and equilibrium credit rationing. Quarterly Journal of Economics 102:135-45.

Woodford, M. 1996. Control of the public debt: A requirement for price stability? NBER Working Paper no. 5684. Cambridge, Mass.: National Bureau of Economic Research, July.

2000. Interest and prices. Princeton University, Department of Economics. Unpublished Manuscript.

\section{Comment Nouriel Roubini}

This is an interesting and important contribution to the literature on exchange rates and balance sheet effects. In a previous paper (Cespedes, Chang, and Velasco 2000, hereafter CCV), the authors showed that flexible rate regimes dominate fixed rate regimes even when one considers the balance sheet effects deriving from liability dollarization (large stock of foreign currency debt).

The intuition for such a result was simple: If an external shock — such as an increase in the world interest rate or a fall in the demand for exports requires a real devaluation, such devaluation can occur in two ways: via a nominal depreciation under flexible exchange rates, or via a domestic deflation under fixed exchange rates.

Thus, under both regimes there are going to be negative balance sheet effects when shock hits the economy; these effects imply contractions in output in both regimes. However, under fixed rates the output effects of the shock will be larger because, if nominal wages are rigid, deflation exacerbates the contraction in output and employment.

The question addressed in this new paper by the authors is whether this result holds when monetary policy is time inconsistent under the discre-

Nouriel Roubini is associate professor of economics at the Stern School of Business, New York University, and a research associate of the National Bureau of Economic Research. 
tionary flexible rate regime. Fixed exchange rates may thus be superior to flexible rates as they are a commitment device that may provide lower inflation levels and variability.

The main result of the paper is that, under three alternative discretionary flexible exchange rate regimes, the welfare losses are lower than under fixed rate regimes.

Note that the role of balance sheet effects in currency crises has been considered by recent theoretical literature on this subject. Contributions include Chang and Velasco (1999); CCV; Krugman (1999); Gertler, Gilchrist, and Natalucci (2000); Aghion, Bacchetta, and Banerjee (2000); Christiano, Gust, and Roldós (2000); Caballero and Krishnamurthy (2000); Kiyotaki and Moore (1997).

On the empirical side, a number of studies have looked at the implications of balance sheet effect; studies include Gelos and Werner (1999); Broda (2000); Frankel (2000); Schaechter, Stone, and Zelmer (2000); Blejer et al. (2000); and Dornbusch (chap. 16 in this volume).

Although part of the analytical literature has addressed the question of the relative performance of fixed versus flexible exchange rates, other researchers have analyzed the actual performance of emerging markets under alternative exchange rate regimes. Such studies include Borensztein, Zettelmeyer, and Philippon (2000); Calvo and Reinhart (1999, 2000); and Hausman (1999). The latter authors have stressed that flexible exchange rates lead to a fear of floating hypothesis and that flexible rates are not desirable in an environment in which liabilities are dollarized (the "original sin" that does not allow an emerging market long-term borrowing in its own currency).

One of the limitations of the CCV paper is that it does not present a survey of this literature on balance sheet effects and thus explain its contribution relative to the rest of the literature. Since there are many related analytical contributions with a similar analytical approach (open-economy variants of the Bernanke-Gertler "financial accelerator" model) and similar results, presenting this contribution in the context of the literature would have been useful.

I will discuss first the arguments against flexible exchange rates, because this paper presents the argument that flexible rates dominate fixed rates. Calvo and Reinhart $(1999,2000)$ and Hausman's (1999) "fear of floating" hypothesis can be summarized as follows:

1. Emerging-market (EM) economies often have a history of high inflation or hyperinflation and lack of fiscal discipline. Thus, they need policy credibility and something to anchor inflation expectations. Fixed rates anchor expectations, whereas flexible rates leave too much room for discretion, and this means high nominal and real interest rates when credibility is imperfect. Also, sensitivity to U.S. Fed tightening is stronger under flexible 
rates. Finally, given that exchange rates are often not driven by fundamentals, especially when credibility is limited, there is excessive exchange rate volatility, which is harmful to trade and economic performance.

2. Because of a history of high inflation, debt restructurings and defaults, and limited policy credibility, emerging markets suffer from "original sin": they are unable to borrow long term in their own currency. Thus, their external debt is mostly short-term and in foreign currency. Worse, most of these countries are effectively liability dollarized - that is, most of their domestic debt, bank deposits, and other liabilities are also in dollars.

3. Because of imperfect policy credibility and effective dollarization, these emerging markets with alleged flexible rate regimes do not have monetary independence and autonomy. Their monetary policy is procyclical, not countercyclical. When a negative shock hits them, such as a terms-of-trade shock or a cutoff from international capital markets because of contagion, they are forced to increase interest rates while their currency is falling. Thus, they do not receive the benefits of a falling currency (they effectively peg) and they still pay the real costs of high nominal and real interest rates.

4. Being subject to original sin and liability dollarization means that devaluations and flexible exchange rates are not effective tools to deal with external imbalances. Devaluations lead to recessions (they are contractionary rather than expansionary) because they have strong balance sheet effects: firms, banks, and private agents as well as the government suffer financial distress when the currency moves.

5. Since they are dollarized, they cannot use the exchange rate tool to $a b$ sorb external shocks such as a terms-of-trade shock, a reduction in world demand for domestic goods, or similar shocks. The exchange rate does not work as a shock absorber for these external shocks.

6. Given all of the above, some argue that it is better to fully dollarize.

Is this "fear of floating" justified? Only partially: flexible exchange rates have provided some monetary autonomy and ability to respond to external shocks and thus successfully minimize the real effects of such disturbances even when economies are partially dollarized. Indeed, evidence and experience with flexible exchange rates in recent years, as well as some recent academic research, suggest that the arguments against flexible exchange rates are exaggerated, for reasons that include the following:

1. Policy credibility is gained with sound policies, not with the choice of the exchange rate regime. Fixed rates do not necessarily provide monetary or fiscal discipline, as the collapse of many pegs proves.

2. There is only partial liability dollarization in EMs (little in Asia, South Africa, and other EMs), and sound policies may lead over time to a reduction in the degree of dollarization. Brazil has more financial indexation than liability dollarization.

3. There is some degree of monetary autonomy under flexible rates. 
Borensztein and Zettelmeyer find that floaters are less sensitive to Fed tightening than fixers. In 1997-99, it was appropriate for floaters to increase interest rates in the face of external shocks. Even fixers were forced to tighten a great deal due to the financial turmoil. (However, see some different evidence by Frankel 2000).

4. Devaluations are contractionary under fixed rates because this regime leads to a buildup of foreign currency liabilities. Depreciations are less likely to be contractionary under flexible exchange rates. Moreover, negative balance sheet effects also occur in fixed rate regimes when there are shocks that require a real depreciation $(\mathrm{CCV})$.

5. Flexible exchange rates provide some shock-absorbing functions when there are terms-of-trade shocks (Broda 2000): the real exchange rate depreciates, and output falls less, under flexible rates. This is also consistent with the experience of recent years (Taiwan and Singapore versus Hong Kong; Chile, Brazil, Peru, and Mexico versus Argentina).

Now, let us go back and consider the argument in favor of flexible exchange rates in the CCV paper and the related analytical literature. In my view, the main problems with current work on balance sheet effects and the choice of exchange rate regime are as follows.

Such studies compare a regime of flexible exchange rates with a regime of fixed exchange rates that is maintained in the face of pressures deriving from external shocks. They do not compare fixed exchange rates with a move to flexible exchange rates that derives from a currency crisis (a collapse in a pegged regime).

This issue is important because evidence from all recent currency crises shows that, once a peg is broken, there is a significant overshooting of the nominal and real exchange rates. That is, while current models assume that nominal and real exchange rates change only as much as is warranted by economic fundamentals (the size of the shock), evidence shows that once a peg is broken and an economy moves to float there is significant overshooting beyond what is warranted by traditional economic fundamentals.

This implies that balance sheet effects are very severe when the move to floating exchange rates is a result of a currency collapse. When the exchange rate overshoots following a collapse, the balance sheet effects are extremely severe and are a source of widespread financial distress in the corporate and banking system. This distress is the source of the excessively contractionary effects of a move to a float when a peg breaks.

There are many examples of this overshooting phenomenon. For example, in Korea the won/dollar exchange rate depreciated from about 900 won to the U.S. dollar to 1,800 (at the peak of the crisis in 1998) and then appreciated back to 1,200 by the end of 1998. In Indonesia, the rupiah/dollar exchange rate depreciated from about 2,200 to 16,000 (at the peak of the crisis in 1998) and then appreciated back to $7,000-8,000$ by $1999-2000$. 
Note that, while the competitive benefits of a weaker yen for Korean firms were sizeable at 1,200 won, at 1,800 won most of these firms were effectively bankrupt or in financial distress, given the large amount of foreign currency-denominated debt. This phenomenon was even more pronounced in the case of Indonesia, where the very sharp and extreme depreciation of the rupiah bankrupted a large part of the corporate and financial system.

Similar overshooting of nominal and real exchange rates occurred in Mexico, Thailand, Brazil, and, partly, Russia during their currency crises. The reversal of real exchange rates after the initial overshooting occurred both through a nominal appreciation and an increase in the price level via inflation. Evidence shows that the long-term real depreciation is much smaller than peak real depreciation.

Given net foreign currency liabilities of these economies, these collapses of fixed pegs resulted in a sharp fall in economic activity in all these countries. The extent of the fall is related to the magnitude of these balance sheet effects.

Most recently, serious concerns about the balance sheet effects of a devaluation played an important role in the official sector's decision to rescue countries such as Turkey. The effects of a depreciation following a break in the peg were estimated to be severe on the balance sheets of these countries.

$\mathrm{CCV}$ and the other contributions to this literature are unable to capture these disruptive effects of a sharp fall of currency value after a currency crisis, because in all of these models the exchange rates are driven only by fundamentals, and no overshooting occurs. Indeed, to capture these empirically relevant balance sheet effects, one needs a model in which such overshooting does occur. Indeed, in a recent work in progress, Perri, Kisselev, Cavallo, and I (Perri, Roubini, Kisselev, and Cavallo 2001) develop such a model of overshooting and balance sheet effects in which lack of currency hedging before a currency crisis and heavy exposure to foreign currency debt lead to short-run overshooting of exchange rates. The implications of such a model are tested for a sample of twenty-three currency crises in the last decade. We estimate a simultaneous equations model to evaluate quantitatively the determinants of overshooting and output contraction.

First, we find that the amount of exchange rate overshooting is related to the heaviness of a country's debt burden and to the degree to which the currency composition of external assets and liabilities is mismatched. In particular, we find that a 1 percent increase in the ratio of net foreign debt to gross (GDP) causes on average an overshooting of the exchange rate of 0.9 percent, therefore confirming that insufficient hedging is related to overshooting.

Second, we find that the main predictor of the degree of output contraction is the product of the net debt term and the total amount of devaluation (fundamental plus overshooting) term. In particular, we find that countries 
with small or negative net foreign debt experience small or negative contractions following a devaluation (regardless of the size of the devaluation). This finding confirms the balance sheet hypothesis that relates the contractionary effect of devaluations to the amount of liabilities denominated in foreign currency.

We conclude by decomposing the output consequence of devaluations in two effects: the direct effect that depends on the size of net debt and on the size of the fundamental devaluation, and the indirect effect that depends on the amount of overshooting. In countries with large net foreign debt, both these effects are large, and so currency crises can be severely contractionary.

I have a few other comments on the CCV paper. CCV find that flexible rates dominate fixed rates even in a model in which discretionary monetary policy (flexible rates) suffers from a time-inconsistency problem. CCV find that these results do not depend on their parameter specification. How robust are these results? The following may be some open issues.

In the CCV model, monetary policy is time inconsistent but does not suffer from the Barro-Gordon "inflation-bias" problem. If an "inflation bias" were present in the model, fixed rates would dominate flexible rates for some specification of preferences: In fact, if the inflation bias of the monetary authorities is large enough, equilibrium inflation would be large enough under discretionary flexible rates that fixed rate regimes would end up dominating flexible rate regimes. Thus, the traditional results in the literature that fixed rates (a device for commitment to low inflation) may be superior to flexible rate discretion would still hold.

In the $\mathrm{CCV}$ welfare function, the measure of inflation is given by wage inflation rather than the more traditional consumer price index (CPI) inflation. This specification choice may bias the results in favor of flexible rate regimes. In fact, note that under both strict and flexible inflation targeting the volatility of nominal and real exchange rates is very high. Thus, CPI inflation that depends on the price of imported goods would also be highly volatile (because purchasing power parity holds for tradeables) when the nominal exchange rate is highly volatile. Instead, wage inflation is more sluggish given the Calvo adjustment assumption in the paper. Thus, the specification of inflation in the welfare function may bias the results in favor of fixed rates. Consequently, it may be worth conducting the same welfare analysis using the traditional definition of inflation.

$\mathrm{CCV}$ use, for welfare analysis, the one-period loss function of the monetary authority rather than the more traditional discounted sum of losses in all periods. Although the former function is the limit, for the discount factor going to zero, of the latter, it may be worthwhile to perform the analysis using the latter to test whether the results are sensitive to this specification.

Moreover, in the model the real responses to international capital market shocks are small, but in the real world they are much sharper. In the CCV 
model, shocks to international capital markets are modeled as increases in the world interest rate. Such shocks have very modest effects on output as investment falls, but the risk premium falls too. Also, the increase in interest rates is sharp but only very temporary.

This does not square with the reality faced by EM economies, where the most important shocks are not the usually modest increases in international interest rates but the much sharper reductions in international capital market access that take two forms: sharp exogenous increases in the risk premium for emerging markets, as captured by large increases in Emerging Markets Bond Index (EMBI) spreads; and sudden cutoffs in the ability of EMs to borrow in international capital markets ("sudden stops").

To consider in a more realistic setting the relative performance of fixed and flexible exchange rates, one would have to consider the response of the model economy to exogenous large shocks to the risk premium faced by an emerging market. In that setup, it is not clear whether flexible rates would be superior to fixed.

Of course, in both regimes, authorities will be faced with unpleasant tradeoffs: under a fixed rate regime, nominal and real interest rates sharply increase to prevent a devaluation, and recessionary effects are the outcome. Additionally, under flexible rates, if the authorities decide not to increase interest rates, the exchange rate will sharply depreciate (even beyond what is warranted by fundamentals if there is excessive volatility of asset prices); in that case, the balance sheet effects may be large, and the loss of inflation credibility may also be large if policy makers already suffer a lack of policy credibility.

Alternatively, policy makers under flexible rates may respond to the shock by sharply tightening interest rates to minimize devaluation effects and the ensuing balance sheet and inflation-confidence effects. However, in this case, the contractionary effects on output may be similar to those under fixed exchange rates.

Thus, we do not know a priori which regime would be superior when an EM suddenly experiences a "sudden stop" or a sharp exogenous increase in the international investors' risk aversion.

In conclusion, this is an interesting and valuable contribution. However, there are a number of issues in the comparison between fixed and flexible exchange rates that this paper has not fully addressed. In particular, although in the long run a regime of flexible exchange rates may dominate one of fixed rates, in the short run the relevant comparison is between the costs of maintaining fixed rates versus moving to flexible rates through a currency crisis; such a move to flexible rates via a currency collapse and exchange rate overshooting may lead to balance sheet effects that may be severely contractionary. This is an empirical phenomenon that current models of balance sheet effects and exchange rates have not addressed. 


\section{References}

Aghion, Philippe, Philippe Bacchetta, and Abhijit Banerjee. 2000. Currency crises and monetary policy with credit constraints. Harvard University. Mimeograph.

Blejer, Mario, Alain Ize, Alfredo Leone, and Sergio Werlang. 2000. Inflation targeting in practice: Strategic and operational issues and application to emerging market economies. Washington, D.C.: International Monetary Fund, August.

Borensztein, Eduardo R., Jeromin Zettelmeyer, and Thomas Philippon. 2000. Monetary independence in emerging markets: Does the exchange rate regime make a difference? IMF Working Paper no. WP/01/1. Washington, D.C.: International Monetary Fund, January. Available at [http://www.imf.org/external/ pubs/ft/wp/2001/wp0101.pdf].

Broda, Christian. 2000. Coping with terms of trade shocks: Pegs vs. floats. American Economic Review 91 (2): 376-80.

Caballero, Ricardo, and Arvind Krishnamurthy. 2000. Emerging market crises: An asset market perspective. Massachusetts Institute of Technology, Sloan School of Business. Unpublished Manuscript.

Calvo, Guillermo A., and Carmen M. Reinhart. 1999. Fixing for your life. NBER Working Paper no. 8006. Cambridge, Mass.: National Bureau of Economic Research, November.

2000. Fear of floating. NBER Working Paper no. 7993. Cambridge, Mass.: National Bureau of Economic Research, November.

Céspedes, Luis, Roberto Chang, and Andres Velasco. 2000. Balance sheets and exchange rate policy. NBER Working Paper no. 7840. Cambridge, Mass.: National Bureau of Economic Research, August.

Chang, Roberto, and Andres Velasco. 1999. Liquidity crises in emerging markets: Theory and policy. NBER Working Paper no. 7272. Cambridge, Mass.: National Bureau of Economic Research, July.

Christiano, Lawrence J., Christopher Gust, and Jorge Roldós. 2000. Monetary policy in an international financial crisis. International Monetary Fund, research department. Mimeograph.

Frankel, Jeffrey. 2000. No single currency is right for all countries at all times. Graham Lecture presented at Princeton University, May.

Gelos, Gaston, and Alejandro Werner. 1999. Financial liberalization, credit constraints, and collateral-investment in the Mexican manufacturing sector. IMF Working Paper no. WP/99/25. Washington, D.C.: International Monetary Fund, March.

Gertler, Mark, Simon Gilchrist, and Fabio Natalucci. 2000. External constraints on monetary policy and the financial accelerator. New York University. Mimeograph.

Hausmann, Ricardo. 1999. Should there be five currencies or one hundred and five? Foreign Policy 116:65-79.

Kiyotaki, Nobuhiro, and John Moore. 1997. Credit cycles. Journal of Political Economy 105:211-48.

Krugman, Paul. 1999. Balance sheets, the transfer problem, and financial crises. Massachusetts Institute of Technology. Mimeograph. January. Available at [http:// web.mit.edu/krugman/www/FLOOD.pdf].

Perri, Fabrizio, Nouriel Roubini, Kate Kisselev, and Michele Cavallo. 2001. Exchange rates overshooting and the costs of floating. New York University, Stern School of Business. Unpublished Manuscript.

Schaechter, Andrea, Mark Stone, and Mark Zelmer. 2000. Adopting inflation targeting: Practical issues for emerging market countries. Washington, D.C.: International Monetary Fund, December. 


\section{Discussion Summary}

On the related literature, Sebastian Edwards commented that the discussion of contractionary devaluation and balance sheet effects is preceded by the work of Guillermo Calvo (and others). The most memorable episode of this kind was in the 1970s and 1980s and related to the whole discussion of the Southern Cone liberalization. The reason that Chile did not devalue at that time was that every single large bank had a very large dollarized liability. This was also the reason that the Chilean banking system had to be nationalized and taken over by the government at the cost of 60 percent of the GDP.

Edwards agreed with the discussant, Nouriel Roubini, that the paper should be clearer on what the relevant comparison is, that is, what system flexible rates should be compared with. However, he did not agree with the discussant's suggestion that the two exchange rate systems should be compared during an exchange rate overshooting, that is, starting from a currency crisis. The question of whether to float from a period of tranquility is very important because many countries are facing this problem right now. One example is Chile's dilemma: whether to follow Argentina and fix its exchange rate to the dollar or follow Mexico to float. Also, Guatemala-located between El Salvador, which will dollarize, and Mexico, which is floating - should make a decision in a tranquil economic situation.

Edwards expressed his surprise regarding the last comparison of the discretional policy to the policy of flexible inflation with real exchange rate targeting. He had expected to see that the flexible inflation with real exchange rate targeting would come last. He speculated that this is not the case because in the model the real exchange rate targeting does not generate huge inflationary inertia due to the way the Calvo-style staggered contracts work. In another framework (which Carlos A. Végh used in his work), real exchange rate targeting will be very costly due to inflationary inertia.

Jorge Braga de Macedo remarked that, in his view, it is too simple to focus on corner solutions, especially if one wants to draw policy implications from the analysis. For example, in the fixed corner, there is a vast difference between dollarization and monetary union.

Roberto Rigobon commented that the paper seems to treat what he thought were the means of monetary policy as the objectives of the policy. For example, pure inflation targeting and imperfect inflation targeting appear as the objectives of the policy in the paper, whereas Rigobon thought inflation targeting referred to the way monetary policy was conducted independent of the objective of the central bank. His related point was that if different targets are treated as objectives, one can't compare welfare losses: it is like comparing two models with different utility functions, he said.

Paolo Pesenti commented on the choice of welfare metric. He observed 
that the loss function is ad hoc and unrelated to the positive model of the paper. He suggested that the Rotemberg-Woodford quadratic approximation could provide a more appropriate welfare metric. Secondly, he said that the model is skewed a priori against fixed exchange rates. The parameters are chosen so that there is no Barro-Gordon-style inflationary bias, thus ruling out the possibility that a fixed exchange rate rule may be preferred to discretion in monetary policy. Instead, in a setup in which the pass-through is not 100 percent, the economy is highly open, and there is monopolistic competition, optimization under discretion would entail a large inflation bias that would make the fixed rate regime more appealing than what appears in the framework of the paper.

Carlos A. Végh said that he liked what the paper was trying to do, but not how it did it. He was wondering why the authors did not study the optimal policy simply by looking at the policy that maximizes the household's welfare or the combination of the households and workers' welfare.

Rudi Dornbusch pointed out that the bias against fixed rates in the paper could be due to equation (9), which contains the real balances (M/P) in the households' and workers' preferences. The specification with real balances in the preferences implies a preference towards volatility.

Roberto Chang agreed with the discussant that the choice of exchange rate regime starting from a crisis period is very important, but, as pointed out by Edwards, it is also an important question during a tranquil period. It is not obvious whether these two issues can be studied in one setting, and the paper focuses on the second question.

On the technical issues, first, he said the paper is well specified. The model is solved by taking log-linear approximation around the nonstochastic steady state. If one takes uncertainty seriously and looks at correctly specified dynamic stationary equilibrium of an economy, then risk premium will be a true random variable and will have different expectation and variance. This paper did not address this point, but it is important. The approach of the paper is justified by concerns of tractability, which approach also explains why the loss function is ad hoc in the model.

He also commented on Végh's question of specifying the welfare function as the welfare of the inhabitants of the economy, given that the paper has fully specified a general equilibrium problem. He said that the paper wanted to postpone this question because the authors are not sure about the objectives of the central bank (i.e., whether it is benevolent). There is also a complication when dealing with this question, that is, how to approximate the welfare function of the agents of an open economy with a quadratic function. The paper chose the most tractable method, although in recent work he and others have been developing approaches that are more general.

Regarding Rigobon's comments, he noted that the paper followed Svensson's (2000) usage of the term targeting. 